\title{
Z problematyki zakazu reformationis in peius w postępowaniu sądowoadministracyjnym
}

\section{Wprowadzenie}

W postępowaniu cywilnym i karnym, a także w procedurze administracyjnej występuje znany od dawna zakaz reformationis in peius. Tę instytucję procesową w sposób najbardziej ogólny zdefiniować można jako zakaz polegający na tym, że sąd lub organ administracji publicznej nie może pogorszyć położenia odwołującej się strony, o ile druga ze stron procesowych nie wniosła środka odwoławczego ${ }^{1}$. Zapewnienie takiej gwarancji ma zapobiegać sytuacjom, w których strona niezadowolona z orzeczenia rezygnowałaby z jego zaskarżenia z powodu obaw, że jej sytuacja ulegnie pogorszeniu w wyniku wydania orzeczenia w postępowaniu odwoławczym. Dzięki ograniczeniu uprawnień orzeczniczych sądu lub organu II instancji poprzez ów zakaz najgorszym efektem zaskarżenia orzeczenia może być utrzymanie go w mocy ${ }^{2}$. Ponadto wprowadzanie do procedur prawnych wspomnianego zakazu motywowane jest koniecznością uniknięcia wewnętrznej sprzeczności ustawy. Jeżeli bowiem przyznaje się stronie prawo do wniesienia środka zaskarżenia, które służyć ma obronie jej interesu, to - jak się wydaje - nie powinno

${ }^{1}$ Por. T. Rowiński, Motywy zakazu reformationis in peius w polskim procesie cywilnym, "Zeszyty Naukowe Uniwersytety Łódzkiego. Nauki Humanistyczno-Społeczne” 1963, z. 31, s. 133.

2 Por. T. Woś, Zakaz reformationis in peius w postępowaniu sądowoadministracyjnym, w: Postępowanie sądowoadministracyjne, pod red. T. Wosia, Warszawa 2015, s. 274; A. Oklejak, Apelacja w procesie cywilnym, Kraków 1994, s. 110 i n. 
się dopuszczać możliwości powstania negatywnych konsekwencji dla strony w przypadku skorzystania z tego uprawnienia ${ }^{3}$.

Również w postępowaniu sądowoadministracyjnym przewidziany został zakaz zmiany na gorsze, chroniący składającego środek prawny. Ze względu jednak na szczególny przedmiot tego postępowania, jakim jest sprawa sądowoadministracyjna, czyli kontrola działalności administracji publicznej przez sąd administracyjny ${ }^{4}$, problematyka dotycząca tej instytucji procesowej budzi wiele kontrowersji i wątpliwości zarówno w doktrynie, jak i w orzecznictwie sądowym. Dlatego też warto dokonać pogłębionej analizy tego zagadnienia.

\section{Kwestia obowiązywania zakazu reformationis in peius w postępowaniu sądowoadministracyjnym}

W uchylonym dziale VI Ustawy z dnia 14 czerwca 1960 r. - Kodeks postępowania administracyjnego ${ }^{5}$, który dotyczył zaskarżania decyzji do sądu administracyjnego, brak było regulacji przewidującej zakaz reformationis in peius w postępowaniu przed Naczelnym Sądem Administracyjnym (NSA). Zgodnie jednak z art. 211 k.p.a.: „W sprawach nie uregulowanych w niniejszym dziale stosuje się odpowiednio przepisy Kodeksu postępowania cywilnego; rozpoznanie skargi następuje według przepisów tego Kodeksu o postępowaniu rewizyjnym". Z kolei art. 382 Ustawy z dnia 17 listopada 1964 r. - Kodeks postępowania cywilnego ${ }^{6}$ stanowił: „Sąd nie może uchylić lub zmienić wyroku na niekorzyść strony wnoszącej rewizję, chyba że strona przeciwna również wniosła rewizję"7 ${ }^{\prime 7}$ Kwestią sporną w doktrynie było to, czy zakaz reformationis in peius, przewidziany w procedurze cywilnej, obowiązuje także poprzez odpowiednie stosowanie przytoczonego przepisu k.p.c. w postępowaniu przed sądem administracyjnym.

${ }^{3}$ Por. B. Adamiak, Postępowanie przed wojewódzkim sądem administracyjnym, w: B. Adamiak, J. Borkowski, Postepowanie administracyjne i sadowoadministracyjne, Warszawa 2014, s. 441 .

${ }^{4}$ Por. J.P. Tarno, Przedmiot i zasady postępowania sadowoadministracyjnego, w: W. Chróścielewski, J.P. Tarno, Postępowanie administracyjne i postępowanie przed sądami administracyjnymi, Warszawa 2016, s. 363.

${ }^{5}$ Tekst jedn. Dz.U. 2016, poz. 23 ze zm., dalej "k.p.a.”.

${ }^{6}$ Tekst jedn. Dz.U. 2016, poz. 1822 ze zm., dalej „k.p.c.".

${ }^{7}$ Przepis w brzmieniu obowiązującym do dnia 30 VI 1996 r. 
Analizując przedstawiony problem, M. Wyrzykowski nie opowiedział się wprost za dopuszczeniem stosowania art. 382 k.p.c. w procedurze sądowoadministracyjnej, ponieważ uznawał, iż zakaz reformationis in peius ma zastosowanie wyłącznie w odniesieniu do uprawnień merytorycznych sądu. Zauważał jednak, że mogą zdarzyć się przypadki, w których ostatecznym rezultatem kasacyjnego orzeczenia sądu administracyjnego będzie pogorszenie sytuacji strony. Jako przykład podawał przypadek stwierdzenia przez sąd nieważności decyzji przyznającej stronie pewne uprawnienie, które w ten sposób zostaje przez nią utracone. Zdaniem autora w ówczesnym stanie prawnym nie istniała jednak możliwość oddalenia skargi ze względu na to, że orzeczenie sądowe doprowadzi do takiego negatywnego efektu. Dlatego też widział potrzebę stworzenia regulacji, dzięki której strona wnosząca skargę do NSA miałaby zapewnioną gwarancję niepogorszenia swojej sytuacji ${ }^{8}$.

Możliwości stosowania art. 382 k.p.c. w postępowaniu przed NSA początkowo nie dopuszczał W. Siedlecki, ze względu na charakter kompetencji orzeczniczych tego sądu. Uważał bowiem, że w odróżnieniu od sądu rewizyjnego w postępowaniu cywilnym NSA, nie rozpoznając spraw pod względem merytorycznym, nie mógł orzec mniej korzystnie dla skarżącego. Jednak także ten autor dostrzegał, iż kasacyjne orzeczenie sądu administracyjnego, co prawda, w sposób bezpośredni nie spowoduje pogorszenia sytuacji strony, lecz może doprowadzić do tego pośrednio, gdy nowa decyzja wydana przez organ administracji będzie mniej korzystna dla strony skarżącej ${ }^{9}$.

Komentując wyrok NSA z 15 września 1982 r. ${ }^{10}$, W. Siedlecki zmodyfikował swój pogląd $\mathrm{w}$ analizowanej kwestii ${ }^{11}$. We wskazanym orzeczeniu sąd przyjął, że "[s]tosownie do art. 382 k.p.c., który na podstawie art. 211 k.p.a. powinien być odpowiednio stosowany w postępowaniu przed Naczelnym Sądem Administracyjnym, sąd nie może uchylić zaskarżonej decyzji na niekorzyść strony wnoszącej skargę, skoro strona przeciwna decyzji tej nie zaskarżyła". Wspomniany autor uznał, że nie należy w sposób generalny wykluczać zastosowania zakazu reformationis

${ }^{8}$ Zob. M. Wyrzykowski, Sadownictwo administracyjne w Polskiej Rzeczypospolitej Ludowej, Warszawa 1983, s. 140-141.

${ }^{9}$ Zob. W. Siedlecki, Stosowanie przepisów k.p.c. w postępowaniu przed Naczelnym Sądem Administracyjnym, „Państwo i Prawo” 1981, z. 2, s. 60.

${ }^{10}$ Wyrok NSA z 15 IX 1982 r., sygn. II SA 909/82, niepublikowany.

${ }^{11}$ Zob. W. Siedlecki, Glosa do wyroku NSA z 15 IX 1982 r., II SA 909/82, "Państwo i Prawo" 1983, z. 9, s. 149 i n. 
in peius $\mathrm{w}$ postępowaniu przed sądem administracyjnym, szczególnie w przypadku, gdy skarżacy żąda uchylenia decyzji tylko w takim zakresie, $\mathrm{w}$ jakim jest ona dla niego niekorzystna ${ }^{12}$. W. Siedlecki podkreślił jednak, że sąd administracyjny ma szczególne kompetencje orzecznicze i w związku z tym przedstawioną wyżej tezę NSA należałoby uzupełnić o stwierdzenie następującej treści: „NSA jednak, stwierdziwszy określone w przepisach art. 207 k.p.a. przyczyny, uzasadniające stwierdzenie nieważności zaskarżonej decyzji administracyjnej lub uzasadniające ograniczenie się do stwierdzenia jej niezgodności z prawem, orzeka z urzędu zgodnie z tymi przepisami niezależnie od treści skargi"13.

Podobny pogląd w tej kwestii przedstawił T. Woś, uznając, że NSA powinien respektować zakaz reformationis in peius, lecz granice tego ograniczenia muszą być wyznaczone $\mathrm{z}$ uwzględnieniem różnic pomiędzy procedurą sądowoadministracyjną a cywilną (rewizyjną). W związ$\mathrm{ku} \mathrm{z}$ tym autor również stał na stanowisku, iż w sytuacji stwierdzenia przez NSA przyczyn uzasadniających stwierdzenie nieważności zaskarżonej decyzji art. 382 k.p.c. nie będzie mógł być zastosowany. T. Woś podkreślił, że waga wad decyzji, które zgodnie z art. $156 \S 1$ k.p.a. uzasadniają stwierdzenie jej nieważności, powoduje, iż w imię ochrony zasady praworządności należy wyeliminować $\mathrm{z}$ obrotu prawnego ten wadliwy akt, nawet jeżeli skutkiem tego działania będzie pogorszenie sytuacji prawnej strony ${ }^{14}$.

Odmienny sposób podejścia zaprezentował A.N. Wróblewski. W jego ocenie prawo cywilne i prawo administracyjne przyjmuja na swoje potrzeby inną treść zakazu reformationis in peius, a w związku z tym nie można przenosić do prawa administracyjnego, w którym temu zakazowi nadano szczególną treść, instytucji stosowanej w prawie cywilnym, nawet jeżeli teoretycznie pozwala na to ogólne odesłanie ustawowe. Autor twierdził zatem, że art. 382 k.p.c. nie ma zastosowania w postępowaniu przed sądem administracyjnym. Jego zdaniem przepisem wyrażającym zakaz reformationis in peius na użytek prawa administracyjnego jest art. 139 k.p.a. ${ }^{15}$, zgodnie z którym: „Organ odwoławczy nie może wydać decyzji na niekorzyść strony odwołującej się, chyba że

${ }^{12}$ Ibidem, s. 151.

${ }^{13}$ Ibidem, s. 153.

14 Zob. T. Woś, Glosa do wyroku SN z 25 I 1984 r., III ARN 23/83, "Orzecznictwo Sądów Polskich i Komisji Arbitrażowych" 1985, nr 10, poz. 196, s. 496-497.

${ }^{15}$ Zob. A.N. Wróblewski, Granice skargi a granice jej rozpoznania przez NSA. Problemy stosowania art. 206 k.p.a., „Państwo i Prawo” 1984, z. 1, s. 73-74. 
zaskarżona decyzja rażąco narusza prawo lub rażąco narusza interes społeczny". Krytycznie odniósł się do tej tezy Z. Matynia, który twierdził, że przeniesienie na grunt postępowania przed NSA zakazu z przytoczonego wyżej przepisu k.p.a. oznacza w istocie brak zakazu reformationis in peius, ponieważ $\mathrm{w}$ wyjątku dotyczącym rażącego naruszenia prawa „wyczerpuje się cała właściwość sądu administracyjnego"16. Ten przedstawiciel doktryny uważał ponadto, że generalnie w postępowaniu sądowoadministracyjnym zakaz zmiany na gorsze nie może obowiązywać i w związku z tym nie zgadzał się ze stanowiskiem Sądu Najwyższego (SN), który w wyroku z 25 stycznia $1983 \mathrm{r} .{ }^{17}$ stwierdzil, że "[w] postępowaniu przed Naczelnym Sądem Administracyjnym zakaz reformationis in peius nie jest wyłączony". Wspomniany autor uznawał, że takie założenie jest niebezpieczne z punktu widzenia praworządności, a na dodatek podważa rolę NSA poprzez ograniczenie zakresu kognicji tego sądu ${ }^{18}$.

Również J. Zimmermann stał na stanowisku, że art. 382 k.p.c. nie powinien być stosowany w postępowaniu sądowoadministracyjnym, ponieważ zakaz reformationis in peius "nie odpowiada przyjętemu modelowi ochrony obiektywnego porządku prawnego i stanowi wyłom na rzecz ochrony indywidualnej". Dlatego też twierdził, że w postępowaniu przed NSA powinna istnieć możliwość pogorszenia sytuacji strony, która wnosząc skargę, musi liczyć się z ryzykiem, jakie niesie ze sobą to działanie ${ }^{19}$. Autor bardzo krytycznie odniósł się do wspomnianych wcześniej orzeczeń sądowych, które nakazywały stosowanie zakazu zmiany na gorsze $\mathrm{w}$ postępowaniu sądowoadministracyjnym ${ }^{20}$. Co ciekawe, skrajnie odmiennie patrzył na to zagadnienie S. Dalka, który pisał: "stosowanie zakazu reformationis in peius w postępowaniu przed NSA może się przyczynić m.in. do ugruntowania praworządności socjalistycznej i wzrostu zaufania społeczeństwa do wymiaru sprawiedliwości"21.

Zestawienie powyższych poglądów pokazuje, jak bardzo kontrowersyjna była analizowana kwestia. Prowadzona w doktrynie dyskusja

${ }^{16}$ Z. Matynia, Glosa do wyroku SN z 25 I 1984 r., III ARN 23/83, „Orzecznictwo Sądów Polskich i Komisji Arbitrażowych" 1985, nr 10, poz. 196, s. 498-499.

${ }^{17}$ Wyrok SN z 25 I 1983 r., sygn. III ARN 23/83, „Orzecznictwo Sądu Najwyższego. Izba Cywilna" 1984, nr 9, poz. 163.

${ }^{18}$ Z. Matynia, op. cit., s. 499.

${ }^{19}$ Zob. J. Zimmermann, Polskie sadownictwo administracyjne (uwagi o projekcie ustawy o Naczelnym Sadzie Administracyjnym), „Krakowskie Studia Prawnicze” 1993-1994, s. 42.

${ }^{20}$ Zob. J. Zimmermann, Administracyjny tok instancji, Kraków 1986, s. 137-138.

${ }^{21}$ S. Dalka, Możliwości stosowania zakazu reformationis in peius przed Naczelnym Sądem Administracyjnym, „Państwo i Prawo" 1985, z. 11-12, s. 107-108. 
została przerwana w momencie, gdy prawodawca wyraźnie ustanowił zakaz reformationis in peius w Ustawie z dnia 11 maja 1995 r. o Naczelnym Sądzie Administracyjnym 22. Artykuł 51 tej ustawy stanowił: „Sąd nie jest związany granicami skargi. Sąd nie może jednak wydać orzeczenia na niekorzyść skarżącego, chyba że stwierdzi naruszenie prawa skutkujące stwierdzenie nieważności zaskarżonego aktu". Wprowadzone zostało zatem rozwiązanie kompromisowe, gdyż stworzono zasadę zakazu zmiany na gorsze, od której przewidziano możliwość odstąpienia w przypadku wykrycia najcięższych wad aktu zakwestionowanego poprzez wniesienie skargi ${ }^{23}$.

Regulacja dotycząca zakazu reformationis in peius, mająca praktycznie identyczną treść, została następnie zamieszczona w Ustawie $\mathrm{z}$ dnia 30 sierpnia 2002 r. - Prawo o postępowaniu przed sądami administracyjnymi ${ }^{24}$. W art. $134 \S 1$ p.p.s.a. w sposób bardziej precyzyjny sformułowano wówczas zasadę niezwiązania sądu granicami skargi. Przepis ten stanowi: "Sąd rozstrzyga w granicach danej sprawy, nie będąc jednak związany zarzutami i wnioskami skargi oraz powołaną podstawą prawną, z zastrzeżeniem art. 57a"25. Natomiast samo unormowanie dotyczące instytucji zakazu zmiany na gorsze ujęto w osobnej jednostce redakcyjnej, czyli w art. 134 § 2 p.p.s.a., zgodnie z którym "Sąd nie może wydać orzeczenia na niekorzyść skarżącego, chyba że stwierdzi naruszenie prawa skutkujące stwierdzeniem nieważności zaskarżonego aktu lub czynności". Jedyna zmiana brzmienia analizowanego przepisu polegała zatem na dodaniu zwrotu "lub czynności". Dzięki temu zabiegowi teoretycznie nie powinno budzić wątpliwości, że zakaz reformationis in peius ma zastosowanie przy rozpatrywaniu skarg na wszelkiego rodzaju przejawy działania organów administracji publicznej przewidziane $\mathrm{w}$ katalogu przedmiotów zaskarżenia z art. $3 \S 2$ p.p.s.a. ${ }^{26} \mathrm{~W}$ rzeczywistości jednak problematyczną kwestią jest ustalenie tego, w odniesieniu do których przypadków zakaz reformationis in peius powinien być

${ }^{22}$ Dz.U. Nr 74, poz. 368 ze zm., dalej „ustawa o NSA”.

${ }^{23}$ Szerzej na temat tego wyjątku: K. Gruszecki, Obowiazywanie zakazu "reformationis in peius" w postępowaniu przed Naczelnym Sądem Administracyjnym, "Państwo i Prawo" 1998 , z. 3, s. 28 i n.

${ }^{24}$ Tekst jedn. Dz.U. 2016, poz. 718 ze zm., dalej „p.p.s.a.”.

${ }^{25}$ Przepis w brzmieniu nadanym na mocy art. 1 pkt 33 Ustawy z dnia 9 IV 2015 r. o zmianie ustawy - Prawo o postępowaniu przed sądami administracyjnymi (Dz.U. poz. 658). Dodano wówczas zwrot "z zastrzeżeniem art. 57a”.

${ }^{26}$ Por. W. Federczyk, Uwagi na temat obowiązywania zakazu reformationis in peius w postępowaniu sądowoadministracyjnym, „Kwartalnik Prawa Publicznego” 2004, nr 3, s. 159. 
stosowany, a względem których jest on bezprzedmiotowy ${ }^{27}$. Poważne rozbieżności w orzecznictwie wywoływała zwłaszcza kwestia dotycząca tego, czy sąd administracyjny, orzekając w sprawie ze skargi na indywidualną interpretację przepisów prawa podatkowego, zobowiązany jest do przestrzegania wspomnianego zakazu ${ }^{28}$. W uchwale składu siedmiu sędziów NSA z 7 lipca 2014 r. (sygn. II FPS 1/14) ( $^{29}$ przyjęto, że przepis art. 134 \& 2 p.p.s.a. nie ma zastosowania w przypadku zaskarżenia do sądu administracyjnego indywidualnej interpretacji przepisów prawa podatkowego ${ }^{30}$. Pogląd ten nie jest jednak powszechnie akceptowany przez przedstawicieli doktryny ${ }^{31}$.

\section{Wykładnia art. 134 § 2 p.p.s.a. wobec kasacyjnych uprawnień orzeczniczych wojewódzkich sądów administracyjnych}

Chociaż nie ma już wątpliwości co do tego, że zakaz reformationis in peius obowiązuje $\mathrm{w}$ postępowaniu sądowoadministracyjnym, to nadal istnieją duże problemy interpretacyjne związane $\mathrm{z}$ tą instytucjac procesową. W doktrynie i orzecznictwie podkreśla się, że ustalenie treści zakazu z art. $134 \S 2$ p.p.s.a. jest poważnie utrudnione ${ }^{32}$. Często

${ }^{27}$ Zob. szerzej: T. Woś, Komentarz do art. 134, w: Prawo o postępowaniu przed sądami administracyjnymi. Komentarz, pod red. T. Wosia, Warszawa 2016, s. 796-797; zob. też K. Gruszecki, op. cit., s. 35.

${ }^{28}$ Za brakiem możliwości stosowania przez sąd administracyjny zakazu reformationis in peius $\mathrm{w}$ stosunku do indywidualnych interpretacji opowiedziano się $\mathrm{np}$. w: wyroku NSA z 27 VI 2012 r., sygn. II FSK 2608/10, "Orzecznictwo Sądów Polskich” 2013, nr 6, poz. 59; wyroku NSA z 5 IV 2012 r., sygn. II FSK 1475/10, „Centralna Baza Orzeczeń Sądów Administracyjnych" - http://orzeczenia.nsa.gov.pl (CBOSA). Natomiast konieczność stosowania tego zakazu w odniesieniu do tej kategorii przedmiotów zaskarżenia uznano np. w: wyroku NSA z 17 V 2012 r., sygn. II FSK 2114/10, CBOSA; wyroku NSA z 22 XII 2008 r., sygn. I FSK 1389/07, CBOSA.

${ }^{29}$ Uchwała składu siedmiu sędziów NSA z 7 VII 2014 r., sygn. II FPS 1/14, „Orzecznictwo Naczelnego Sądu Administracyjnego i wojewódzkich sądów administracyjnych” („ONSAiWSA”) 2015, nr 1, poz. 3.

${ }^{30}$ Podobnie: M. Szubiakowski, Glosa do wyroku NSA z 17 VI 2012 r., II FSK 2608/10, "Orzecznictwo Sądów Polskich" 2013, nr 6, poz. 59, s. 417 i n.

${ }^{31}$ Zob. np.: S. Gajewski, Glosa do uchwaty NSA z 7 VII 2014 r., II FPS 1/14, LEX/el. 2014; A. Drywa, Glosa do wyroku NSA z 1 X 2014 r., II FSK 2399/12, "Gdańskie Studia Prawnicze Przegląd Orzecznictwa" 2015, nr 1, s. 60 i n.

${ }^{32}$ Zob. np.: J.P. Tarno, Prawo o postępowaniu przed sądami administracyjnymi. Komentarz, Warszawa 2012, s. 348; E. Ochendowski, Postępowanie administracyjne i postępowanie przed sadem administracyjnym. Wybór orzecznictwa, Torun 1996, s. 223; M. Jagielska, J. Jagielski, 
prezentowany jest pogląd, zgodnie z którym określenie tego, czy przyjęte $\mathrm{w}$ wyroku rozstrzygnięcie nie narusza zakazu z art. 134 p.p.s.a., wymaga wnikliwego rozważenia przez sąd w każdej sprawie osobno ${ }^{33}$. W gruncie rzeczy potwierdza to fakt, iż nie została wypracowana ogólna koncepcja teoretyczna odnosząca się do treści zakazu reformationis in peius $\mathrm{w}$ postępowaniu przed sądem administracyjnym, która byłaby powszechnie akceptowana i użyteczna w praktyce. Problem tkwi w tym, że sądy administracyjne co do zasady nie wydają orzeczeń merytorycznych. Podstawowe uprawnienia orzecznicze sądu I instancji to oddalenie skargi - oznaczające utrzymanie zaskarżonego aktu (czynności) w mocy, albo uwzględnienie skargi - polegające na wyeliminowaniu zaskarżonego aktu (czynności) z obrotu prawnego ze względu na jego sprzeczność z prawem. Skutkiem wyroku uwzględniającego skargę jest to, że sprawa wraca do organu administracji publicznej, który zobowiązany jest ponownie ją rozpatrzyćc ${ }^{34}$. Wobec tego w doktrynie odrzuca się możliwość rozumienia niekorzyści, o której mowa w art. 134 § 2 p.p.s.a. w sensie materialnym, gdyż sąd administracyjny - na co zwracano uwagę już od dawna - nie może swoim orzeczeniem kasacyjnym bezpośrednio pogorszyć materialnoprawnej sytuacji strony ${ }^{35}$.

Rzeczą zrozumiałą jest to, że przedstawiciele nauki, bazując na powyższych założeniach, podjęli próby ustalenia, na czym w takim razie może polegać owa "niekorzyść" dla skarżącego. Najbardziej kompleksowej analizy tego zagadnienia dokonał J. Zimmermann jeszcze w czasie obowiązywania ustawy o NSA. Autor ten zaprezentował tezę, zgodnie z którą niekorzyść determinująca zakaz reformationis in peius w postępowaniu sądowoadministracyjnym może być spowodowana wyłącznie w trzech sytuacjach: (1) uchylenia aktu w części niezaskarżonej;

R. Stankiewicz, Komentarz do art. 134, w: Prawo o postępowaniu przed sądami administracyjnymi. Komentarz, pod red. R. Hausera, M. Wierzbowskiego, Warszawa 2015, s. 572; zob. też np. wyrok NSA z 6 V 2010 r., sygn. I FSK 345/09, CBOSA.

${ }^{33}$ Por. A. Kabat, Komentarz do art. 134, w: Prawo o postępowaniu przed sadami administracyjnymi. Komentarz, pod red. B. Dautera, A. Kabata, M. Niezgódki-Medek, Warszawa 2016, s. 600; por. też np.: wyrok NSA z 5 VII 2013 r., sygn. II OSK 2602/11, CBOSA; wyrok NSA z 23 I 2015 r., sygn. I OSK 2037/14, CBOSA; wyrok Wojewódzkiego Sądu Administracyjnego (WSA) w Warszawie z 3 XII 2013 r., sygn. III SA/Wa 1181/13, CBOSA.

${ }^{34}$ Por. J.P. Tarno, Orzeczenia sądowe, w: W. Chróścielewski, J.P. Tarno, op. cit., s. 472.

${ }^{35}$ Por. J. Zimmermann, Zakaz reformationis in peius w postępowaniu administracyjnym i w postępowaniu sądowo-administracyjnym, w: Księga Pamiątkowa profesora Eugeniusza Ochendowskiego, Toruń 1999, s. 365; T. Woś, Komentarz do art. 134, w: Prawo..., pod red. T. Wosia, s. 795; J.P. Tarno, Prawo..., s. 439. 
(2) zastosowania środka ostrzejszego od tego, o który zabiegała strona; (3) sformułowania oceny prawnej, która zdeterminowałaby wydanie w przyszłości aktu pogarszającego sytuację materialnoprawną skarżącego w porównaniu z jego sytuacją wynikającą z zaskarżonego aktu ${ }^{36}$. Pomimo zmiany stanu prawnego pogląd J. Zimmermanna nadal bardzo często w doktrynie i orzecznictwie uznawany jest za aktualny ${ }^{37}$. W celu dokonania oceny prawidłowości zaprezentowanej tezy warto bliżej przyjrzeć się każdemu z trzech przedstawionych wyżej przypadków.

Zdaniem J. Zimmermanna pod rządami ustawy o NSA zakaz reformationis in peius $\mathrm{w}$ postępowaniu sądowoadministracyjnym w sposób wyraźny przeciwstawiony był zasadzie niezwiązania sądu granicami skargi. Jednoznacznie wskazywała na to treść art. 51 wspomnianej ustawy. Przy czym istotne jest to, że granice skargi wyznaczone są w kilku płaszczyznach, a mianowicie przez zakres zaskarżenia, zarzuty oraz wnioski skarżącego. Autor podkreślał, że zakaz orzekania na niekorzyść podmiotu wnoszącego środek prawny nie powoduje związania NSA zarzutami i wnioskami skargi, ponieważ to nie do nich należy odnosić poniesioną przez skarżącego niekorzyści. Wiązana ona być powinna jedynie z treścią i obowiązywaniem zaskarżonego aktu. Natomiast w kontekście zakresu, w jakim akt został zaskarżony, zakaz reformationis in peius wyłącza zasadę niezwiązania sądu granicami skargi. W związku z tym J. Zimmermann stwierdził, że NSA nie może orzec o niezgodności z prawem tej części aktu, która nie została zakwestionowana przez skarżącego, ponieważ w takim przypadku sąd pozbawiłby ten podmiot prawa lub takiej konkretyzacji stosunku prawnego, co do której nie ma on zastrzeżeń. Dodatkowo autor wskazał, iż wniosek taki potwierdzony jest też faktem obowiązywania w postępowaniu przed NSA zasady skargowości ${ }^{38}$. W istocie oznacza to, że niezależnie od tego, czy w postępowaniu sądowoadministracyjnym obowiązuje zakaz reformationis in peius, niedopuszczalne jest działanie sądu administracyjnego

\footnotetext{
${ }^{36}$ Zob. J. Zimmermann, Zakaz..., s. 366.

${ }^{37}$ Zob. np.: J.P. Tarno, Prawo..., s. 349; A. Krawczyk, Rozpoznanie sprawy i wydanie orzeczenia przez wojewódzki sąd administracyjny, w: Polskie sq̨downictwo administracyjne - zarys systemu, pod red. Z. Kmieciaka, Warszawa 2015, s. 186; wyrok NSA z 29 X 2015 r., sygn. I GSK 361/14, CBOSA; wyrok NSA z 13 VIII 2015 r., sygn. I OSK 1124/15, CBOSA; wyrok NSA z 25 XI 2010 r., sygn. I OSK 854/10, CBOSA.

${ }^{38}$ Por. J. Zimmermann, Zakaz..., s. 364-365; podobnie: M. Jagielska, J. Jagielski, R. Stankiewicz, Komentarz do art. 134, w: Prawo..., pod red. R. Hausera, M. Wierzbowskiego, s. 572.
} 
I instancji polegające na uchyleniu niezaskarżonej części decyzji, gdyż jest ono wykroczeniem poza granice rozpoznawanej sprawy. Podobnie na tę kwestię patrzy J.P. Tarno, który uważa, że sąd nie może uczynić przedmiotem swojego rozpoznania niezaskarżonej części decyzji, gdyż w tym zakresie nie doszło do wszczęcia postępowania sądowoadministracyjnego. Innymi słowy, sąd nie jest uprawniony do oceny zgodności z prawem całego aktu w sytuacji, gdy strona zaskarżyła go tylko w części $^{39}$. W ocenie autorki niniejszego artykułu nie jest to właściwe podejście do analizowanego problemu. Trzeba zgodzić się ze stanowiskiem T. Wosia, który twierdzi, że zasada niezwiązania sądu granicami skargi oznacza, iż nie jest on związany zarzutami i wnioskami skarżącego, ale też zakresem zaskarżenia danego aktu ${ }^{40}$.

Za prawidłowe należy uznać założenie, że granice rozpoznania sprawy oraz orzekania przez wojewódzki sąd administracyjny wyznaczone są rozstrzygnięciem zawartym w zaskarżonym akcie ${ }^{41}$. W odniesieniu do kwestii zakresu zaskarżenia stwierdzenie to ma charakter dwuaspektowy. Z jednej strony mamy tu do czynienia z wytyczną dla sądu, która przyjmuje postać ograniczenia. Sąd nie może bowiem wyjść poza granice rozpoznawanej sprawy, czyli wkroczyć w nową sprawę poprzez kontrolę aktu, który mógłby być odrębnym przedmiotem zaskarżenia ${ }^{42}$. $Z$ drugiej zaś strony wojewódzki sąd administracyjny zobowiązany jest do podjęcia pełnej kontroli w granicach danej sprawy, czyli zbadania legalności całości zaskarżonego aktu oraz postępowania prowadzącego do jego wydania. Wyznaczenie przez stronę zakresu zaskarżenia nie powinno stanowić podstawy do zwolnienia sądu z obowiązku kontroli zgodności z prawem całości aktu zakwestionowanego poprzez wniesienie skargi. Może być ono traktowane jedynie jako informacja ukierunkowująca proces badania legalności danego aktu ${ }^{43}$.

Istotne jest to, że wśród wymienionych $\mathrm{w}$ art. $57 \S 1$ p.p.s.a. elementów, które musi zawierać skarga, znajduje się jedynie wymóg wskazania

${ }^{39}$ Zob. J.P. Tarno, Prawo..., s. 346; podobnie: A. Wróbel, Postępowanie sądowoadministracyjne, w: K. Chorąży, W. Taras, A. Wróbel, Postępowanie administracyjne, egzekucyjne i sądowoadministracyjne, Kraków 2003, s. 324.

${ }^{40}$ Zob. T. Woś, Zakaz reformationis in peius..., s. 275.

${ }^{41}$ Por. Z. Kmieciak, Glosa do wyroku WSA w Gliwicach z 27 X 2004 r., II SA/Ka 2352/02, "Orzecznictwo Sądów Polskich" 2007, nr 3, poz. 25, s. 163.

${ }^{42}$ Por. A. Krawczyk, Rozpoznanie sprawy..., s. 185.

${ }^{43}$ Por. wyrok NSA z 25 X 2011 r., sygn. II OSK 1716/10, CBOSA; zob. też wyrok NSA z 13 IV 2007 r., sygn. II GSK 384/06, CBOSA; wyrok NSA z 19 VIII 2004 r., sygn. FSK 377/04, CBOSA. 
zaskarżonego aktu lub czynności. Ustawodawca nie przewidział natomiast obowiązku określenia przez skarżącego zakresu zaskarżenia, a więc tego, czy kwestionuje on całość czy tylko część aktu lub czynności ${ }^{44}$. W związku z tym przedmiotem skargi jest zawsze określony akt (czynność), ponieważ w tym kontekście musi on być postrzegany jako pewien monolit. Można zasadnie sądzić, że zaskarżenie aktu tylko w określonym zakresie powinno być przez sąd traktowane jako nieprzedstawienie przez skarżącego zarzutów i wniosków w odniesieniu do pozostałej części tego aktu, a owymi zarzutami i wnioskami sąd i tak nie jest związany.

Ponadto trudne do zaakceptowania byłyby konsekwencje przyjęcia założenia, zgodnie z którym sąd I instancji nie może uchylić aktu w niezaskarżonej części, gdyż naruszyłby w ten sposób zakaz reformationis in peius. Taka supozycja oznacza, iż sąd nie będzie uprawniony do tego, aby uchylić akt w części niezaskarżonej, pomimo że w tym zakresie ów akt jest niezgodny z prawem, a sąd dostrzega, iż wynikająca z tej części aktu sytuacja prawna strony powinna być przez organ administracji ukształtowana w sposób obiektywnie korzystniejszy dla skarżącego. Jednocześnie w pełni dopuszczalne będzie uchylenie przez sąd aktu w części zaskarżonej, nawet jeżeli istnieje bardzo duże prawdopodobieństwo, że w wyniku ponownego rozstrzygnięcia sprawy przez organ administracji pogorszeniu ulegnie sytuacja prawna strony. Moga przecież zdarzać się przypadki, gdy skarżący bezzasadnie kwestionuje korzystne dla siebie rozstrzygnięcie, nie zdając sobie sprawy z tego, jakie mogą być skutki takiego działania.

Należy przyznać, że konstrukcja art. 51 ustawy o NSA rzeczywiście dawała podstawy do traktowania zakazu reformationis in peius jako wyjątku od zasady niezwiązania sądu granicami skargi. Jednak w obecnym stanie prawnym unormowanie dotyczące zakazu orzekania na niekorzyść skarżącego wyraźnie oddzielone jest od przepisu statuującego wspomnianą zasadę. W związku z tym zasadne jest twierdzenie, że relacja między tymi regulacjami procesowymi ma zupełnie inny charakter. Artykuł 134 p.p.s.a. dotyczy szeroko rozumianych granic rozstrzygania przez sąd administracyjny. Przewidziane tam w dwóch paragrafach wytyczne odnoszące się do zakresu swobody działania sądu określone zostały przy uwzględnieniu różnych kryteriów. Zgodnie z przepisem

${ }^{44}$ Odmiennie ukształtowany został analogiczny wymóg dotyczący skargi kasacyjnej. Wyraźnie stwierdzono, że powinna ona zawierać oznaczenie zaskarżonego orzeczenia sądowego ze wskazaniem, czy jest ono zaskarżone w całości czy w części - zob. art. 176 $\S 1$ pkt 1 p.p.s.a. 
§ 1 tego artykułu sąd uprawniony jest do rozstrzygania w granicach danej sprawy, a nie tylko w granicach wyznaczonych przez skarżącego. Chodzi tu zatem o dopuszczalny zasięg podejmowanej kontroli i orzekania przez sąd. Natomiast art. $134 \S 2$ p.p.s.a. wprowadza ograniczenie uprawnień sądu przy kształtowaniu treści orzeczenia. Mamy więc do czynienia z normatywnie wyznaczonymi zakresami kompetencji sądu w dwóch niepokrywających się płaszczyznach. Wobec tego właściwy jest wniosek, że nie należy traktować zakazu reformationis in peius jako ograniczenia zasady niezwiązania sądu granicami skargi ${ }^{45}$. Można natomiast przyjąć, że prawidłowe jest stwierdzenie, iż sąd administracyjny I instancji, rozstrzygając w granicach danej sprawy, zobowiązany jest do przestrzegania zakazu zmiany na gorsze. Oznacza to, że zarówno w przypadku, gdy sąd wykracza poza granice skargi, jak i wówczas, gdy nie stwierdza istnienia potrzeby wyjścia poza te ramy, związany jest zakazem reformationis in peius, który powinien być tu interpretowany jako niedopuszczalność pogorszenia przez sąd sytuacji prawnej skarżącego.

W tym miejscu warto zwrócić uwagę na wyrok NSA z 17 maja 2012 r. $^{46}$, w którym sąd stwierdził, że „orzeczeniem na niekorzyść strony skarżącej $\mathrm{w}$ rozumieniu art. 134 § 2 p.p.s.a. będzie każde orzeczenie, które pogarsza sytuację skarżącego w stosunku do tej, jaką miał przed wniesieniem skargi, przy czym pogorszenie to nie musi dotyczyć wyłącznie jego praw czy obowiązków wynikających z prawa materialnego, ale także pewnych uprawnień faktycznych czy procesowych, powstałych w [wyniku] wydania zaskarżonego aktu bądź dokonania czynności". Istotne jest to, że przedstawiona teza została sformułowana w orzeczeniu dotyczącym indywidualnej interpretacji przepisów prawa podatkowego. Biorąc pod uwagę fakt, iż kwestia dopuszczalności stosowania instytucji zakazu reformationis in peius w sprawach dotyczących tej kategorii przedmiotów zaskarżenia budzi wiele kontrowersji, można mieć pewne wątpliwości co do tego, czy wskazany wyżej sposób definiowania pojęcia "orzeczenia na niekorzyśćc jest godny zaaprobowania i czy nadaje się do uniwersalnego wykorzystania ${ }^{47}$. NSA zakreślił znaczenie tego sformułowania w sposób niezwykle szeroki, a przy tym wysoce niejasny. Trudne

${ }^{45}$ Odmiennie: T. Woś, Zakaz reformationis in peius..., s. 275.

${ }^{46}$ Wyrok NSA z 17 V 2012 r., sygn. II FSK 2114/10, CBOSA.

${ }^{47}$ Ten sposób interpretacji mocno upowszechnił się w orzecznictwie - zob. np.: wyrok NSA z 5 IV 2016 r., sygn. II FSK 377/14, CBOSA; wyrok NSA z 21 IX 2015 r., sygn. I FSK 220/14, CBOSA; wyrok NSA z 7 VII 2015 r., sygn. I OSK 2969/13, CBOSA; wyrok NSA z 27 III 2014 r., sygn. II FSK 980/12, CBOSA. 
do ustalenia jest przede wszystkim to, czym w istocie są "uprawnienia faktyczne", o których wspomina NSA.

Potwierdzić należy, że istnieją pewne akty organów administracji, przy weryfikacji których zastosowanie ma zasada zakazu reformationis in peius, lecz "niekorzyść" nie jest wówczas rozumiana jako uszczerbek w materialnoprawnej sytuacji skarżącego. Przykładowo, jest tak $\mathrm{w}$ odniesieniu do wąskiej grupy postanowień wydawanych w postępowaniu administracyjnym (np.: art. $88 \S 1$, art. 96, art. $264 \S 2$ k.p.a. $)^{48}$. Dla obowiązywania wspomnianego zakazu nie jest przeszkodą to, że rozstrzygnięcia takie dotyczą kwestii proceduralnych, a nałożone obciążenia nie wynikają z przepisów prawa materialnego. W związku z tym analizowana teza NSA jest częściowo trafna. Sąd słusznie dostrzegł potrzebę szerszego spojrzenia na rodzaj przepisów będących podstawą nałożenia obowiązków lub przyznania praw określonemu podmiotowi. Niemniej jednak przedmiotem porównań dokonywanych na potrzeby stosowania zakazu zmiany na gorsze musi być zawsze wymiar skonkretyzowanych przez organ obowiązków lub uprawnień skarżącego, ponieważ - jak się wydaje - włącznie tej sfery dotyczyć może zakaz reformationis in peius. Brak jest natomiast podstaw do traktowania tego ograniczenia kompetencji orzeczniczych sądu jako instytucji pełniącej funkcję gwarancyjną w obszarze uprawnień i obowiązków procesowych. Dlatego też przyjąć należy, że norma zawarta w art. $134 \S 2$ p.p.s.a. nie oznacza zakazu pogorszenia przez sąd szeroko rozumianej sytuacji skarżącego ${ }^{49}$. Takie ujęcie byłoby zbyt pojemne. W kontekście omawianej instytucji procesowej znaczenie może mieć jedynie ocena zmian w sytuacji prawnej podmiotu wnoszącego skargę; mówiąc ściślej, chodzi o to, czy wydanie przez sąd orzeczenia określonej treści doprowadzi do uszczuplenia uprawnień skarżącego lub nałożenia na niego większej liczby obciążeń w stosunku do stanu wynikającego z zaskarżonego aktu lub czynności. Dodać także należy, że działanie sądu musi mieć charakter zobiektywizowany. Sąd administracyjny nie jest władny oceniać wpływu, jaki wywrze jego orzeczenie na ogólną sytuację faktyczną skarżącego, a w szczególności na subiektywne odczucia tego podmiotu czy dalsze konsekwencje wydania orzeczenia ${ }^{50}$.

${ }^{48}$ Zob. szerzej: A. Skóra, Reformatio in peius w postępowaniu administracyjnym, Gdańsk 2002, s. 171 i n.

${ }^{49}$ Odmiennie: A. Drywa, op. cit., s. 65.

${ }^{50}$ Por. rozważania J. Zimmermanna na temat cech „niekorzyści”, o której mowa w art. 139 k.p.a. - J. Zimmermann, Zakaz..., s. 359. 
Trudno też zgodzić się z tezą J. Zimmermanna, że niekorzyść może być spowodowana zastosowaniem przez sąd środka ostrzejszego niż ten, o który zabiegał skarżący (np. stwierdzenie nieważności aktu zamiast jego uchylenia) ${ }^{51}$. Przede wszystkim twierdzenie to stoi w sprzeczności z przyjętymi przez autora słusznymi założeniami sprowadzającymi się do tego, że niekorzyść musi mieć charakter obiektywny, a także - jak już wcześniej wspomniano - nie powinna być wiązana z zarzutami i wnioskami skargi ${ }^{52}$. Gdyby uznać, że żądania skarżącego muszą być brane pod uwagę przy ocenie tego, czy orzeczenie sądu jest dla niego niekorzystne, to okazałoby się, iż wyrok sądu polegający na oddaleniu skargi może być uznawany za naruszający zakaz reformationis in peius. Takie rozumowanie jest nie do przyjęcia ze względu na fakt, że w przypadku gdy sąd administracyjny oddala skargę, sytuacja prawna strony nie ulega zmianie, a więc z pewnością nie można mówić o jej pogorszeniu. Oczekiwania strony, która wniosła skargę, polegające np. na żądaniu uchylenia decyzji, nie mogą być traktowane jako punkt odniesienia przy ocenie tego, czy doszło do wydania orzeczenia na niekorzyśćs3.

Ponadto sąd w przypadku uwzględnienia skargi de facto nie ma swobody w doborze środków stosowanych wobec zaskarżonych aktów lub czynności, które okazały się niezgodne z prawem, gdyż ustawa określa przesłanki wydania danego rodzaju rozstrzygnięcia. Przede wszystkim to typ stwierdzonego naruszenia prawa determinuje konieczność zastosowania przez sąd określonego środka ${ }^{54}$. Istotne jest też to, że w odniesieniu do niektórych kategorii przedmiotów zaskarżenia istnieje tylko jeden możliwy sposób eliminacji wadliwego aktu lub czynności ${ }^{55}$.

Przechodząc do rozważań na temat ostatniego z zaproponowanych przez J. Zimmermanna sposobów spowodowania "niekorzyści” będącej konsekwencją wyroku sądu administracyjnego, należy najpierw zwrócić uwagę na to, że aby można było mówić o stwierdzeniu istnienia "niekorzyści", rozumianej jako pogorszenie sytuacji prawnej skarżącego, musi być możliwe dokonanie porównania tej sytuacji wynikającej z dwóch

${ }^{51}$ Zob. ibidem, s. 366; idem, Polskie sadownictwo..., s. 42; pogląd aprobuje E. Ochendowski, op. cit., s. 223.

${ }^{52}$ Zob. J. Zimmermann, Zakaz..., s. 364.

${ }^{53}$ Por. wyrok NSA z 8 IV 2008 r., sygn. II OSK 367/07, CBOSA; zob. też np. wyrok NSA z 21 XII 2006 r., sygn. II FSK 58/06, CBOSA.

${ }^{54}$ Por. W. Siedlecki, Glosa..., s. 150.

${ }^{55}$ Zob. art. $146 \S 1$ i art. 148 p.p.s.a. 
orzeczeń. Wobec tego wyrok polegający na uchyleniu zaskarżonego aktu i skutkujący powrotem sprawy do organu administracji publicznej, który zobowiązany będzie ponownie ją rozpoznać, nie powoduje powstania niekorzyści, o której mowa w art. 134 § 2 p.p.s.a., gdyż sytuacja prawna skarżącego nie zostaje wówczas ustalona. W takim przypadku mamy do czynienia $\mathrm{z}$ powstaniem stanu zawieszenia $\mathrm{w}$ odniesieniu do kwestii ukształtowania sytuacji prawnej podmiotu, który wniósł środek zaskarżenia. Dlatego też sam fakt kasacji, czyli zniesienia aktu lub czynności organu administracji publicznej, nie narusza zakazu reformationis in peius.

Jak słusznie zauważa J. Zimmermann, zakaz zmiany na gorsze nie może być postrzegany jako "tama” przeciwko wydaniu orzeczenia kasacyjnego w sytuacji, gdy sąd dochodzi do wniosku, że w ponownym postępowaniu przed organem administracji może zostać wydany akt mniej korzystny dla strony niż ten, który był przedmiotem zaskarżenia. $\mathrm{W}$ chwili podjęcia rozstrzygnięcia sąd nie jest bowiem $\mathrm{w}$ stanie przewidzieć, w jakim stanie faktycznym i prawnym będzie orzekać organ administracji publicznej ${ }^{56}$. Ponadto, jeżeli akt uchylany jest ze względu na stwierdzenie przez sąd naruszenia przepisów postępowania, które mogło mieć istotny wpływ na wynik sprawy, to tym bardziej nie wiadomo, czy uwzględnienie skargi następuje na korzyść czy niekorzyść skarżacego ${ }^{57}$.

W orzeczeniu uwzględniającym skargę znajdują się jednak elementy mające moc wiążącą w ponownym postępowaniu przed organem administracji publicznej. Są to wyrażone przez sąd oceny prawne i wskazania co do dalszego postępowania, o których mowa w art. 153 p.p.s.a. Zdaniem J. Zimmermanna sąd administracyjny musi brać pod uwagę to, że w przyszłości może dojść do pogorszenia sytuacji skarżącego ze względu na oparcie się przez organ na ocenie prawnej wyrażonej w orzeczeniu sądowym. W związku z tym na tej właśnie płaszczyźnie orzeczenia sąd "powinien trzymać się zakazu reformationis in peius" ${ }^{\prime \prime 8}$. Taki kierunek interpretacji treści zakazu z art. $134 \S 2$ p.p.s.a., zaproponowany przez wspomnianego autora, jest najbardziej upowszechniony w doktrynie i orzecznictwie.

${ }^{56}$ Zob. J. Zimmermann, Zakaz..., s. 365; poddany krytyce sposób interpretacji spotkać można jednak niekiedy w orzecznictwie - zob. np.: postanowienie NSA z 20 IV 2010 r., sygn. II GSK 353/10, CBOSA; wyrok WSA w Krakowie z 7 I 2010 r., sygn. I SA/Kr 723/09, CBOSA; wyrok WSA w Warszawie z 27 X 2009 r., sygn. VII SA/Wa 974/09, CBOSA.

${ }^{57}$ Por. K. Gruszecki, op. cit., s. 34.

${ }^{58}$ J. Zimmermann, Zakaz..., s. 365. 
Przyjmuje się, że w postępowaniu sądowoadministracyjnym "niekorzyść" dla skarżącego może być spowodowana takim sformułowaniem przez sąd oceny prawnej w wyroku uwzględniającym skargę, które zdeterminowałoby wydanie w przyszłości przez organ administracji aktu pogarszającego sytuację prawną skarżącego $\mathrm{w}$ porównaniu $\mathrm{z}$ sytuacją wynikającą z aktu zakwestionowanego poprzez wniesienie skargi ${ }^{59}$. Należy jednak zauważyć, że to, czy wytyczne sądu determinują wydanie mniej korzystnego dla skarżącego rozstrzygnięcia, tak naprawdę da się ustalić dopiero w momencie wydania aktu przez organ administracji po ponownym rozpatrzeniu sprawy. W chwili orzekania przez sąd nie można przewidzieć, czy nie wystąpią w przyszłości zmiany stanu prawnego lub faktycznego sprawy, które spowodują, iż oceny prawne i wskazania sądu ulegną dezaktualizacji lub staną się bezprzedmiotowe. Jeżeli dojdzie do takiej sytuacji, może okazać się, że sąd niepotrzebnie naruszył zasadę praworządności, stosując zakaz reformationis in peius przy formułowaniu wytycznych, o których mowa w art. 153 p.p.s.a. ${ }^{60}$

Najprawdopodobniej ze względu na powyższe wady niekiedy w doktrynie i orzecznictwie prezentowana jest też nieco zmodyfikowana wersja stanowiska J. Zimmermanna, w której nie akcentuje się konieczności wystąpienia efektu w postaci „zdeterminowania” przyszłego pogorszenia sytuacji prawnej skarżącego, ale podkreśla się, że do uznania, iż naruszony został zakaz reformationis in peius, wystarczy samo stwierdzenie, że „zawarte w wyroku oceny i zalecenia mogą w dalszym postępowaniu administracyjnym prowadzić do wydania aktu lub podjęcia czynności pogarszającej sytuację skarżącego" ${ }^{61}$. Jest to zatem ujęcie zdecydowanie szersze, ponieważ w taki sposób wyraźnie wkracza się w sferę przypuszczeń.

Wśród przedstawicieli doktryny będących zwolennikami łączenia zakazu orzekania na niekorzyść skarżącego z instytucją wytycznych,

${ }^{59}$ Zob. T. Woś, Komentarz do art. 134, w: Prawo..., pod red. T. Wosia, s. 795-796; J.P. Tarno, Prawo..., s. 349; zob. też np.: wyrok NSA z 21 IX 2015 r., sygn. I FSK 220/14, CBOSA; wyrok NSA z 25 VII 2008 r., sygn. II OSK 893/07, CBOSA.

${ }^{60}$ Por. B. Majchrzak, Problem określenia skutków obowiązywania zakazu reformationis in peius w postępowaniu przed wojewódzkim sądem administracyjnym, "Przegląd Prawa Publicznego" 2014, nr 11, s. 50.

${ }^{61}$ Zob. A. Kabat, Komentarz do art. 134, w: Prawo..., pod red. B. Dautera, A. Kabata, M. Niezgódki-Medek, s. 601; P. Szustakiewicz, Komentarz do art. 134, w: Prawo o postepowaniu przed sądami administracyjnymi. Komentarz, pod red. A. Skoczylasa, P. Szustakiewicza, Warszawa 2016, s. 244; zob. też np.: wyrok NSA z 5 IV 2014 r., sygn. II FSK 377/14, CBOSA; wyrok NSA z 12 II 2014 r., sygn. II FSK 878/12, CBOSA. 
o których mowa w art. 153 p.p.s.a., są tacy, którzy wyraźnie kładą nacisk na to, że sąd musi brać pod uwagę zakaz reformationis in peius podczas „formułowania" zaleceń wiążących organ administracji ${ }^{62}$. Pogląd ten należy uznać za niesłuszny, ponieważ w istocie oznacza to, że wspomniany zakaz miałby oddziaływać na proces kształtowania przez sąd ocen prawnych, które dotyczą przede wszystkim wykładni przepisów prawa materialnego i procesowego oraz właściwego zastosowania określonych uregulowań jako podstaw rozstrzygnięcia ${ }^{63}$. Niedopuszczalne wydaje się przyjęcie założenia, zgodnie z którym sąd zobowiązany jest do korygowania własnych ocen prawnych ze względu na zasadę określoną w art. $134 \S 2$ p.p.s.a. Mogłoby to bowiem na przykład oznaczać, że na potrzeby konkretnej sprawy sąd byłby zmuszony odstąpić od ugruntowanego w orzecznictwie sposobu interpretacji danego przepisu prawa. Bardziej zasadne jest przyjęcie, że zakaz reformationis in peius musi być brany pod rozwagę tylko w momencie, gdy sąd decyduje o tym, czy skarga powinna być uwzględniona.

W kontekście instytucji zakazu orzekania na niekorzyść skarżącego w postępowaniu sądowoadministracyjnym ważne jest przyjęcie odpowiedniej sekwencji działań sądu. Otóż przeprowadzając kontrolę legalności zaskarżonego aktu, sąd administracyjny w pierwszej kolejności musi zbadać, czy doszło do naruszenia prawa dającego podstawę do uwzględnienia skargi, co miałoby polegać na wydaniu orzeczenia kasacyjnego. Jeżeli odpowiedź jest pozytywna, sąd powinien wyartykułować - jego zdaniem prawidłowe - oceny prawne i wskazania co do dalszego postępowania, o których stanowi art. 153 p.p.s.a. Na samym końcu sąd ma obowiązek zbadać, jaki wpływ mają jego wytyczne na rozstrzygnięcie sprawy przez organ administracji publicznej. Wyraźnie trzeba jednak zaznaczyć, że nie może tu być mowy o jakichkolwiek przewidywaniach sądu w tym przedmiocie. W postępowaniu sądowoadministracyjnym obowiązuje bowiem zasada orzekania według stanu faktycznego i prawnego istniejącego $\mathrm{w}$ dacie podjęcia zaskarżonego aktu lub czynności ${ }^{64}$. Wobec tego, jeżeli sąd stwierdzi, że wchodzące $\mathrm{w}$ grę orzeczenie zawiera oceny prawne, do których zastosowanie się

${ }^{62}$ Zob. np.: J. Zimmermann, Zakaz..., s. 365; P. Szustakiewicz, Komentarz do art. 134, w: Prawo..., pod red. A. Skoczylasa, P. Szustakiewicza, s. 244-245.

${ }^{63}$ Por. J.P. Tarno, Zwiazanie ocena prawna zawarta w wyroku sadu administracyjnego, „Administracja. Teoria - Dydaktyka - Praktyka” 2011, nr 4, s. 186.

${ }^{64}$ Por. J.P. Tarno, Przedmiot i zasady postępowania sądowoadministracyjnego, w: W. Chróścielewski, J.P. Tarno, op. cit., s. 369. 
przez organ administracji publicznej w stanie faktycznym i prawnym istniejącym $\mathrm{w}$ dacie wydania zaskarżonego aktu spowodowałoby podjęcie rozstrzygnięcia mniej korzystnego niż zaskarżone ze względu na obowiązywanie zakazu z art. 134 \& 2 p.p.s.a., powinien oddalić skargę. Oceny prawne i zalecenia przedstawione przez sąd nie będą wówczas pełnić roli wiążących wytycznych dla organu administracji publicznej, lecz ich funkcją będzie umotywowanie rozstrzygnięcia polegającego na oddaleniu skargi.

Z powyższego wynika, że zakaz reformationis in peius może być stosowany przede wszystkim wtedy, gdy sąd stwierdzi jedynie naruszenie prawa materialnego, które miało wpływ na wynik sprawy. Natomiast w sytuacji, kiedy organ administracji publicznej dopuścił się uchybień proceduralnych, nie ustalając w sposób prawidłowy stanu faktycznego sprawy, wspomniany zakaz zasadniczo nie może mieć zastosowania. W takim przypadku sąd właściwie nie jest w stanie określić, jaki wpływ na rozstrzygnięcie organu administracji miałyby jego oceny prawne. Jeżeli jednak stwierdzone zostanie, że co prawda doszło do naruszenia przepisów postępowania, które mogło mieć istotny wpływ na wynik sprawy, lecz w obowiązującym w dacie wydania zaskarżonego aktu stanie prawnym sytuacja prawna skarżącego i tak nie mogłaby być ukształtowana przez organ w sposób korzystniejszy, niż wynika to z zakwestionowanego aktu, sąd administracyjny, kierując się zasadą $z$ art. $134 \S 2$ p.p.s.a., powinien oddalić skargę. Chodzi zatem o przypadki, gdy kierunek zmian w sytuacji prawnej podmiotu wnoszącego skargę mógłby być tylko negatywny ${ }^{65}$. Trzeba też dodać, że w analogiczny sposób ograniczone będą kompetencje orzecznicze sądu administracyjnego $\mathrm{w}$ razie stwierdzenia naruszenia prawa dającego podstawę do wznowienia postępowania administracyjnego. Chociaż mamy tu do czynienia z kategorią ciężkich wad aktu organu administracji publicznej i sąd powinien uwzględnić skargę niezależnie od tego, czy stwierdzone naruszenie ma wpływ na wynik sprawy ${ }^{66}$, to art. $134 \S 2$ p.p.s.a. nie wyłącza w tych przypadkach stosowania zakazu reformationis in peius. Należy jednak zgodzić się z T. Wosiem, że takie rozwiązanie legislacyjne trudno uznać za prawidłowe ${ }^{67}$.

${ }^{65}$ Przykładowo, organ naruszył przepisy postępowania, co mogło mieć istotny wpływ na wynik sprawy, lecz w zaskarżonej do sądu decyzji przyznał skarżącemu określone świadczenie w maksymalnej wysokości przewidzianej w przepisach prawa.

${ }^{66}$ Por. J.P. Tarno, Orzeczenia sądowe, w: W. Chróścielewski, J.P. Tarno, op. cit., s. 473.

${ }^{67}$ Zob. T. Woś, Komentarz do art. 134, w: Prawo..., pod red. T. Wosia, s. 797. 


\section{Stosowanie zakazu reformationis in peius przy wydawaniu orzeczeń merytorycznych przez wojewódzkie sądy administracyjne}

Nowelizacją z dnia 9 kwietnia 2015 r. ${ }^{68}$ rozbudowano kompetencje sądów administracyjnych poprzez rozszerzenie możliwości podejmowania przez nie, w wyjątkowych sytuacjach, rozstrzygnięć o cechach orzeczeń merytorycznych. Dodano wówczas art. 145a, art. $149 \S 1$ b, a także art. $145 \S 3$ p.p.s.a. Obowiązującymi już wcześniej przepisami pozwalającymi sądom administracyjnym na wydawanie tego rodzaju orzeczeń są natomiast art. $146 \S 2$ oraz art. $154 \S 2$ p.p.s.a. ${ }^{69}$ Ta wąska grupa uprawnień jurysdykcyjnych zasługuje na bliższą analizę w kontekście obowiązywania zakazu reformationis in peius, ponieważ ich charakter różni się zasadniczo od kasacyjnych kompetencji orzeczniczych, w odniesieniu do których prowadzone były wcześniejsze rozważania. Od razu warto też zaznaczyć, że w tym obszarze niekorzyść, o której mowa $\mathrm{w}$ art. $134 \S 2$ p.p.s.a., może być rozumiana jako pogorszenie sytuacji skarżącego bezpośrednio przez sąd administracyjny.

Przede wszystkim na uwagę zasługuje art. 145a p.p.s.a. Podstawowym celem tego unormowania jest dyscyplinowanie organów administracji publicznej do wykonywania prawomocnych wyroków wydawanych przez sądy administracyjne. Ze względu jednak na sposób sformułowania przesłanek pozwalających na skorzystanie $\mathrm{z}$ tych uprawnień orzeczniczych możliwość rozstrzygania merytorycznego przez sądy administracyjne jest tu mocno ograniczona ${ }^{70}$. Zgodnie bowiem z art. 145a $\S 1$ p.p.s.a. w przypadku, o którym mowa w art. 145 $\S 1$ pkt 1 lit. a lub pkt 2 p.p.s.a., czyli w sytuacji uwzględnienia skargi na decyzję (postanowienie) wskutek stwierdzenia naruszenia prawa materialnego, które miało wpływ na wynik sprawy, lub stwierdzenia nieważności tego aktu, sąd zobowiązuje organ do wydania w określonym terminie decyzji (postanowienia), wskazując sposób załatwienia sprawy lub jej rozstrzygnięcie, jeżeli jest to uzasadnione okolicznościami sprawy, a rozstrzygnięcia nie pozostawiono uznaniu organu administracji publicznej. Wydając takie orzeczenie, sąd staje się podmiotem

${ }^{68}$ Ustawa z dnia 9 IV 2015 r. o zmianie ustawy - Prawo o postępowaniu przed sądami administracyjnymi (Dz.U. poz. 658).

${ }^{69}$ Por. Z. Kmieciak, Merytoryczne orzekanie przez sady administracyjne w świetle konstytucyjnej zasady podziału władz, „Przegląd Legislacyjny” 2015, nr 2, s. 11.

${ }^{70}$ Por. J.P. Tarno, Orzeczenia sądowe, w: W. Chróścielewski, J.P. Tarno, op. cit., s. 474. 
wpływającym w sposób bezpośredni na treść rozstrzygnięcia sprawy administracyjnej, a więc rzeczywistym decydentem ${ }^{71}$. W tym przypadku to sąd przesądza o tym, jak zostanie ukształtowana materialnoprawna sytuacja strony, gdyż organ administracji nie będzie mógł zmodyfikować treści narzuconego mu rozstrzygnięcia. Z pewnością zatem można dokonać oceny takiego orzeczenia sądowego z punktu widzenia jego korzystności bądź niekorzystności dla skarżącego. W związku z tym sąd administracyjny, wydając orzeczenie na podstawie art. 145a § 1 p.p.s.a., zobowiązany jest do przestrzegania ustanowionego w art. 134 $\S 2$ p.p.s.a. zakazu reformationis in peius. Oznacza to, że sąd, określając sposób załatwienia sprawy lub formułując jej rozstrzygnięcie, musi to uczynić tak, aby nie spowodować uszczerbku w wynikającej z zaskarżonego aktu materialnoprawnej sytuacji strony. Odstapienie od tego ograniczenia jest możliwe tylko w przypadku uwzględnienia skargi z powodu uchybienia stanowiącego podstawę stwierdzenia nieważności decyzji (postanowienia).

Stosownie do $\S 3$ analizowanego artykułu w przypadku niewydania przez organ decyzji (postanowienia), o której mowa w art. 145a $\S 1$ p.p.s.a., w określonym przez sąd terminie strona może wnieść skargę, żądając wydania orzeczenia stwierdzającego istnienie albo nieistnienie uprawnienia lub obowiązku. Wprowadzono jednak zastrzeżenie, że sąd wyda orzeczenie w tym przedmiocie, jeżeli pozwalają na to okoliczności sprawy. Co prawda, w takim wyroku zawarte jest rozstrzygnięcie sprawy administracyjnej, jednak jego treść została już wcześniej określona przez sąd orzeczeniem wydanym na podstawie art. $145 a \S 1$ p.p.s.a. Na tym etapie postępowania sąd nie ma już możliwości zmiany wspomnianego rozstrzygnięcia. Wobec tego zakaz reformationis in peius nie ma tu bezpośredniego zastosowania.

Kolejnym wyjątkiem od kasacyjnego charakteru kompetencji jurysdykcyjnych sądu administracyjnego jest możliwość orzeczenia przez sąd o istnieniu lub nieistnieniu uprawnienia lub obowiązku, jeżeli pozwala na to charakter sprawy oraz niebudzące uzasadnionych wątpliwości okoliczności jej stanu faktycznego i prawnego. Z takiej kompetencji sąd może skorzystać, po pierwsze, w przypadku uwzględnienia skargi na bezczynność lub przewlekłe prowadzenie postępowania przez organy $\mathrm{w}$ sprawach określonych $\mathrm{w}$ art. $3 \S 2$ pkt 1-4 p.p.s.a. albo na przewlekłe prowadzenie postępowania $\mathrm{w}$ sprawach określonych $\mathrm{w}$ art. $3 \S 2$

${ }^{71}$ Por. Z. Kmieciak, Merytoryczne orzekanie..., s. 11. 
pkt 4a p.p.s.a. (art. 149 § 1b p.p.s.a.). Po drugie zaś, sąd może orzec w taki sposób w przypadku niewykonania wyroku uwzględniającego skargę na bezczynność lub przewlekłe prowadzenie postępowania, gdy strona, po uprzednim pisemnym wezwaniu właściwego organu do wykonania wyroku lub załatwienia sprawy, wniosła skargę w tym przedmiocie, żądając wymierzenia temu organowi grzywny (art. 154 $\S 2$ zd. 1 p.p.s.a.). W obu przypadkach sąd orzeka we wskazany sposób w sytuacji, gdy organ nie wydał aktu lub nie dokonał czynności, czyli nie podjął działania. Tutaj zakaz z art. 134 § 2 p.p.s.a. nie będzie miał zastosowania, ponieważ ograniczenie to obowiązuje tylko w sytuacji, gdy przedmiotem zaskarżenia jest konkretny przejaw działania organu. Jeżeli takowego nie ma, sąd nie dysponuje materiałem porównawczym w postaci uprzedniego aktu (czynności), z którym mógłby skonfrontować swoje orzeczenie. $Z$ tych samych względów zakaz reformationis in peius będzie bezprzedmiotowy $\mathrm{w}$ razie orzekania przez sąd na podstawie art. $149 \S 1$ pkt 2 p.p.s.a.

Kontrowersyjną kwestią jest to, w jakiej relacji do siebie pozostaja dwa paragrafy art. 146 p.p.s.a. Stosownie do art. $146 \S 1$ p.p.s.a., uwzględniając skargę na akt lub czynność, o których mowa w art. 3 § 2 pkt 4 i 4 a p.p.s.a., sąd uchyla ten akt (interpretację, opinię zabezpieczającą lub odmowę wydania opinii zabezpieczającej) albo stwierdza bezskuteczność czynności. Natomiast zgodnie z art. 146 § 2 p.p.s.a. „[w] sprawach skarg na akt lub czynność, o których mowa w art. $3 \S 2$ pkt 4 , sąd może w wyroku uznać uprawnienie lub obowiązek wynikające z przepisów prawa". Większość przedstawicieli doktryny twierdzi, że w art. $146 \S 2$ p.p.s.a. określone zostało samodzielne i niezależne od kompetencji orzeczniczej z $\S 1$ tego artykułu uprawnienie sądu, z którego korzysta on w przypadku, gdy organ nie wydał aktu konkretyzującego obowiązek lub uprawnienie, a więc nie podjął działania ${ }^{72}$. Odmienny - w ocenie

${ }^{72}$ Zdaniem J.P. Tarny chodzi tu o sytuację, w której organ odmówił podjęcia aktu konkretyzującego, pomimo że ciąży na nim taki obowiązek, a w związku z tym sąd nie może się odnieść do żadnego aktu - J.P. Tarno, Prawo..., s. 379; natomiast T. Woś uważał, że „art. $146 \S 2$ [p.p.s.a.] dotyczy sytuacji, gdy uprawnienie lub obowiązek wynikają bezpośrednio z przepisów prawa i nie zachodzi potrzeba ich konkretyzowania w formie indywidualnego aktu prawnego", jednak autor ten po zmianie brzmienia art. $146 \S 2$ p.p.s.a. dokonanego w wyniku nowelizacji z 2015 r. (zwrot "w sprawach, o których mowa w $§ 1$ " zastąiono sformułowaniem „w sprawach skarg na akt lub czynność, o których mowa $\mathrm{w}$ art. $3 \S 2$ pkt $4^{\prime \prime}$ ) podaje w wątpliwość ten sposób interpretacji - T. Woś, Komentarz do art. 146, w: Prawo..., pod red. T. Wosia, s. 863; por. też A. Kabat, Komentarz do art. 146, w: Prawo..., pod red. B. Dautera, A. Kabata, M. Niezgódki-Medek, s. 642. 
autorki niniejszego artykułu słuszny - pogląd prezentuje Z. Kmieciak, którego zdaniem orzeczenie wydane na podstawie art. $146 \S 2$ p.p.s.a. zapewnia "fakultatywną i subsydiarną ochronę skarżącemu, sprzężoną z uchyleniem aktu albo stwierdzeniem bezskuteczności czynności zaskarżonych do sądu administracyjnego". Sąd może zatem na podstawie art. $146 \S 2$ p.p.s.a. uznać uprawnienie lub obowiązek wynikające z przepisów prawa tylko w przypadku uwzględnienia skargi na akt lub czynność, o których mowa w art. $3 \S 2$ pkt 4 p.p.s.a., a więc gdy uchyla akt lub stwierdza bezskuteczność czynności na podstawie art. 146 § 1 p.p.s.a. ${ }^{73}$ Jeżeli organ nie podejmuje aktu lub czynności, o których mowa $\mathrm{w}$ art. $3 \S 2$ pkt 4 p.p.s.a., przedmiotem skargi powinna być bezczynność organu lub przewlekłe prowadzenie postępowania (art. $3 \S 2$ pkt 8 p.p.s.a. $)^{74}$. Zastosowanie będzie miał wówczas art. 149 p.p.s.a. ${ }^{75}$

W związku z powyższym, wydając merytoryczne orzeczenie na podstawie art. $146 \S 2$ p.p.s.a., sąd zobowiązany jest do przestrzegania ustanowionego w art. $134 \S 2$ p.p.s.a. zakazu reformationis in peius ${ }^{76}$. Przykładem niech będzie tu przypadek, gdy przedmiotem zaskarżenia jest czynność materialno-techniczna organu gminy polegająca na ustaleniu wysokości opłaty za zezwolenie na sprzedaż napojów alkoholowych ${ }^{77}$. Sąd, w razie zniesienia tej czynności na podstawie art. $146 \S 1$ p.p.s.a., wykorzystując kompetencję orzeczniczą przewidzianą w art. $146 \S 2$ p.p.s.a., nie może uznać obowiązku wniesienia przez stronę tej opłaty w wysokości wyższej niż obliczona przez organ.

Opierając się na art. 145 § 3 p.p.s.a., sąd administracyjny I instancji wydaje szczególny rodzaj orzeczenia. Zgodnie z tym przepisem, w przypadku gdy sąd, uwzględniając skargę na decyzję (postanowienie), uchyla ten akt lub stwierdza jego nieważność, dopatrując się

${ }^{73}$ Z. Kmieciak, Czy sady administracyjne stosuja przepisy prawa materialnego?, "Zeszyty Naukowe Sądownictwa Administracyjnego" 2011, nr 2, s. 13-14.

${ }^{74} \mathrm{~W}$ przypadku kategorii aktów i czynności, o których mowa w art. 3 § 2 pkt 4 p.p.s.a., ustalenie tego, czy konkretne zachowanie organu jest działaniem czy też bezczynnością lub przewlekłym prowadzeniem postępowania, stwarza duże trudności - por. W. Chróścielewski, Glosa do wyroku NSA z 27 X 2015 r., II OSK 269/15, "Orzecznictwo Sądów Polskich" 2016, nr 7-8, poz. 75, s. 1051-1052.

${ }^{75}$ Por. J.P. Tarno, Prawo..., s. 379.

${ }^{76}$ Odmienne stanowisko zajmuje J. Zimmermann, który twierdzi, że merytoryczne orzeczenie tego rodzaju ma charakter deklaratoryjny, potwierdzający istnienie uprawnienia lub obowiązku, a w związku z tym nie może pogorszyć sytuacji skarżącego - zob. J. Zimmermann, Zakaz..., s. 366.

77 Por. uchwałę składu pięciu sędziów NSA z 23 VI 1997 r., sygn. OPK 1/97, „Orzecznictwo Naczelnego Sądu Administracyjnego" 1997, nr 4, poz. 149. 
istnienia podstawy do umorzenia postępowania administracyjnego, umarza jednocześnie to postępowanie. Jest to orzeczenie, które $\mathrm{z}$ formalnego punktu widzenia ma cechy charakterystyczne rozstrzygnięcia kasacyjnego. Dokonuje się w nim zniesienia aktu wydanego przez organ administracji publicznej oraz umorzenia postępowania administracyjnego, co wywołuje jedynie skutek procesowy. Nie dochodzi natomiast do rozstrzygnięcia sprawy administracyjnej w sposób merytoryczny, a więc co do jej istoty. Oznacza to, że sąd nie wypowiada się w kwestii powstania, zmiany lub wygaśnięcia konkretnego stosunku prawnego, którego treścią są określone uprawnienia bądź obowiązki stron. Orzeczenie $z$ art. 145 \& 3 p.p.s.a. nie wywołuje zatem skutku materialnoprawnego ${ }^{78}$. Konsekwencja wydania tego rodzaju wyroku jest jednak definitywne załatwienie sprawy administracyjnej ${ }^{79}$. Orzeczenie sądu zastępuje tu rozstrzygnięcie organu administracji publicznej ${ }^{80}$. Z tego właśnie względu wyrok ten zakwalifikować można do kategorii orzeczeń merytorycznych wojewódzkiego sądu administracyjnego.

$\mathrm{Z}$ pozoru może się wydawać, że zakaz reformationis in peius jest bezprzedmiotowy przy orzekaniu przez sąd na podstawie art. $145 \S 3$ p.p.s.a., ponieważ w tym przypadku nie dochodzi do konkretyzacji normy prawa materialnego w zakresie obowiązków lub uprawnień strony. Jednak sądowe orzeczenie eliminujące akt administracyjny i umarzające postępowanie administracyjne może spowodować niekorzyść materialną dla strony. Do takiej sytuacji dojdzie na przykład, gdy sąd uchyli wadliwą decyzję przyznającą stronie uprawnienie i umorzy postępowanie administracyjne ${ }^{81}$. Wówczas strona w sposób trwały traci uprawnienie, którym dysponowałaby, gdyby nie wniosła skargi do sądu administracyjnego. Wydaje się zatem, że zasada z art. $134 \S 2$ p.p.s.a. blokuje możliwość wydania tego rodzaju rozstrzygnięcia. Dlatego też w sytuacji, gdy sąd dopatrzy się naruszenia prawa dającego podstawę

${ }^{78} \mathrm{O}$ skutku procesowym i materialnoprawnym w odniesieniu do decyzji administracyjnej zob. W. Chróścielewski, Akty kończace postępowanie, w: W. Chróścielewski, J.P. Tarno, op. cit., s. 160.

${ }^{79}$ Por. J.P. Tarno, Orzeczenia sądowe, w: W. Chróścielewski, J.P. Tarno, op. cit., s. 474.

${ }^{80}$ Por. A. Kabat, Komentarz do art. 145, w: Prawo..., pod red. B. Dautera, A. Kabata, M. Niezgódki-Medek, s. 632.

${ }^{81}$ Por. rozważania T. Kiełkowskiego na temat niekorzyści, jaką strona może odnieść w wyniku wydania przez organ odwoławczy decyzji na podstawie art. 138 \& 1 pkt 2 in fine k.p.a. (uchylenie zaskarżonej decyzji i umorzenie postępowania I instancji) T. Kiełkowski, Glosa do wyroku NSA z 28 III 2001 r., II SA/Kr 2674/00, "Państwo i Prawo” 2002, z. 10, s. 116. 
do uchylenia decyzji, na mocy której przyznano stronie uprawnienie, a jednocześnie stwierdzi podstawę do umorzenia postępowania administracyjnego, musi brać pod uwagę obowiązek przestrzegania zakazu reformationis in peius.

\section{Zakaz reformationis in peius w postępowaniu przed Naczelnym Sądem Administracyjnym}

Wśród regulacji dotyczących postępowania przed NSA nie ma unormowania wprowadzającego zakaz reformationis in peius. Jednakże stosownie do art. 193 p.p.s.a., "[j]eżeli nie ma szczególnych przepisów postępowania przed Naczelnym Sądem Administracyjnym, do postępowania tego stosuje się odpowiednio przepisy postępowania przed wojewódzkim sądem administracyjnym [...]". Ze względu na istnienie tego odesłania w doktrynie przyjmuje się, że w postępowaniu kasacyjnym należy odpowiednio stosować art. $134 \S 2$ p.p.s.a. ${ }^{82}$ Pojawia się jednak zasadnicze pytanie, na czym $\mathrm{w}$ istocie polegać ma $\mathrm{w}$ tym przypadku odpowiednie stosowanie wskazanego przepisu.

Podstawowym podejściem do przedstawionego problemu jest przyjęcie założenia, że w postępowaniu przed NSA na mocy art. $134 \S 2 \mathrm{w} z w$. $z$ art. 193 p.p.s.a. obowiązuje zakaz reformationis in peius oznaczający, iż NSA nie może wydać orzeczenia na niekorzyść strony wnoszącej skargę kasacyjną ${ }^{83}$. Warto zaznaczyć, że stroną postępowania w sprawie sądowoadministracyjnej, oprócz skarżącego, jest także organ administracji publicznej, którego działanie, bezczynność lub przewlekłe prowadzenie postępowania było przedmiotem skargi (art. 32 p.p.s.a.). W związku z tym również ten organ korzystałby z ochrony, jaką daje analizowana instytucja procesowa.

Niebywale trudne jest ustalenie tego, jakie skutki wywołuje stosowanie przedstawionej wyżej normy skonstruowanej w wyniku przeprowadzenia odpowiednich modyfikacji art. 134 § 2 p.p.s.a. Pojawia się także fundamentalny problem dotyczący tego, czy od zakazu reformationis in peius chroniącego skarżącego kasacyjnie miałyby istnieć

${ }^{82}$ Zob. B. Adamiak, op. cit., s. 457; J.P. Tarno, Prawo..., s. 523; B. Dauter, Komentarz do art. 193, w: Prawo..., pod red. B. Dautera, A. Kabata, M. Niezgódki-Medek, s. 904.

${ }^{83}$ Por. uchwałę składu siedmiu sędziów NSA z 8 XII 2009 r., sygn. II GPS 5/09, "ONSAiWSA" 2010, nr 3, poz. 40; por. też A. Krawczyk, Postępowanie uruchomione w wyniku wniesienia środka odwoławczego, w: Polskie sądownictwo..., s. 226-227. 
jakiekolwiek wyjątki. Przewidziane przez ustawodawcę odstępstwo od zasady z art. 134 § 2 p.p.s.a. z pewnością nie może być mechanicznie zastąpione okolicznością występowania nieważności postępowania. Niedopuszczalne wydaje się bowiem przyrównywanie przesłanek stwierdzenia nieważności aktu lub czynności do enumeratywnie wymienionych w art. $183 \S 2$ p.p.s.a. przypadków, gdy zachodzi nieważność postępowania. Należy jednak zauważyć, że ustawodawca wyraźnie przewidział, iż NSA z urzędu bierze pod rozwagę nieważność postępowania i gdy stwierdzi, że ta zachodzi, uchyla wyrok także w części niezaskarżonej (art. 186 p.p.s.a.). W związku z tym istnieje podstawa do przyjęcia, że w sytuacji stwierdzenia nieważności postępowania sądowego NSA nie jest związany zakazem reformationis in peius. Taki właśnie pogląd prezentuje na przykład A. Krawczyk, której zdaniem w stadium podjęcia rozstrzygnięcia NSA ograniczony jest wspomnianym zakazem, co oznacza, że „wyjąwszy przypadki nieważności postępowania, nie może on wydać orzeczenia na niekorzyść strony wnoszącej skargę kasacyjną"84. Autorka zakłada zatem, że wyłącznie w przypadkach, gdy zachodzi nieważność postępowania, NSA nie jest związany zakazem reformationis in peius. Z innej perspektywy na tę kwestię zdaje się patrzeć W. Federczyk, który pisze: „Wydaje się, iż NSA orzekając jedynie w granicach skargi kasacyjnej nie może orzec na niekorzyść strony, poza wypadkiem stwierdzenia nieważności postępowania" ${ }^{\prime 85}$. Przy założeniu, że autor ten, używając zwrotu "nie może orzec na niekorzyść", chciał wyrazić myśl, iż rozstrzygnięcie NSA podjęte w granicach wyznaczonych skargą kasacyjną nigdy nie jest niekorzystne dla strony ${ }^{86}$, można stwierdzić, że powyższa teza sprowadza się do tego, iż NSA nie naruszy zakazu reformationis in peius, jeżeli rozstrzyga w granicach skargi kasacyjnej. Do wydania orzeczenia na niekorzyść strony może dojść jedynie wtedy, gdy zachodzi nieważność postępowania, ponieważ tylko w tej sytuacji NSA działa ex officio. Zestawienie dwóch powyższych poglądów prowadziłoby do paradoksalnego wniosku, że w przypadkach, gdy w ogóle dojść może do wydania przez NSA orzeczenia na niekorzyść strony, sąd ten nie jest związany zakazem reformationis in peius.

Jeszcze więcej wątpliwości pojawia się, gdy od rozważań teoretycznych przejdziemy do analizy tego, w jakich sytuacjach NSA rzeczywiście

\footnotetext{
${ }^{84}$ Ibidem.

${ }^{85}$ W. Federczyk, op. cit., s. 162.

${ }^{86}$ Jeżeli ten niejednoznaczny zwrot zostałby zinterpretowany jako zakaz takiego działania sądu, w istocie teza W. Federczyka byłaby zbieżna z poglądem A. Krawczyk.
} 
mógłby naruszyć zakaz orzekania na niekorzyść skarżącego kasacyjnie. Uprawnienia orzecznicze tego sądu mają zasadniczo kasacyjny charakter $^{87}$. Podstawowym rozstrzygnięciem wydawanym przez NSA w przypadku uwzględnienia skargi kasacyjnej jest uchylenie zaskarżonego orzeczenia w całości lub w części i przekazanie sprawy do ponownego rozpoznania wojewódzkiemu sądowi administracyjnemu. Trzymając się ustaleń poczynionych wcześniej w niniejszym opracowaniu, należy uznać, że tego rodzaju rozstrzygnięcie nie narusza zakazu reformationis in peius, ponieważ orzeczenie takie o niczym jeszcze nie przesądza. Zdaniem W. Federczyka w tym przypadku skutkiem odpowiedniego stosowania przez NSA art. $134 \S 2$ p.p.s.a. jest to, że sąd ten, formułując w swoim orzeczeniu wykładnię prawa wiążącą sąd I instancji, któremu sprawa została przekazana (art. 190 p.p.s.a.), powinien brać pod uwage zakaz reformationis in peius ${ }^{88}$. Z przedstawionym poglądem trudno się zgodzić, gdyż instytucja zakazu orzekania na niekorzyść skarżącego o czym już wcześniej wspomniano - nie powinna wpływać na proces interpretacji przepisów prawa.

W odniesieniu do szczególnej kompetencji orzeczniczej NSA, określonej w art. 189 p.p.s.a., w doktrynie i orzecznictwie powstały poważne rozbieżności interpretacyjne. Zgodnie z tym przepisem NSA uchyla zaskarżone orzeczenie oraz odrzuca skargę lub umarza postępowanie sądowe, jeżeli skarga ulegała odrzuceniu albo istniały podstawy do umorzenia postępowania przed wojewódzkim sądem administracyjnym. Zdaniem B. Dautera treść art. 189 p.p.s.a. wskazuje na to, że NSA zobowiązany jest badać z urzędu, czy przed sądem administracyjnym I instancji prawidłowo nadano sprawie bieg. Jeżeli NSA uzna, że istnieją przesłanki do skorzystania z kompetencji określonej w art. 189 p.p.s.a., wydaje na podstawie tego przepisu stosowne orzeczenie i nie może być tu nigdy mowy o naruszeniu przez NSA zakazu reformationis in peius ${ }^{89}$. Ponadto, jak wskazuje J.P. Tarno, unormowanie to stanowi odstępstwo od zasady związania NSA granicami skargi kasacyjnej. Do zastosowania art. 189 p.p.s.a. nie jest wymagane zamieszczenie w skardze kasacyjnej

${ }^{87}$ Por. J.P. Tarno, Zaskarżanie orzeczeń wojewódzkich sądów administracyjnych, w: W. Chróścielewski, J.P. Tarno, op. cit., s. 501.

${ }^{88}$ Zob. W. Federczyk, op. cit., s. 162.

${ }^{89}$ Por. B. Dauter, Metodyka pracy sędziego sądu administracyjnego, Warszawa 2014, s. 524; podobnie: M. Kania, Zwyczajne środki zaskarżenia w postępowaniu przed sąami administracyjnymi, Warszawa 2009, s. 165-166; por. też np.: postanowienie NSA z 1 II 2006 r., sygn. I OSK 386/05, CBOSA; postanowienie NSA z 2 IX 2008 r., sygn. II GSK 310/08, CBOSA. 
stosownego wniosku w tym przedmiocie. Ograniczeniem dla NSA jest tu wyłącznie zakres zaskarżenia. Jeżeli orzeczenie sądu I instancji zostało zaskarżone jedynie w części, to tylko w tym zakresie może ono zostać uchylone i jedynie w tej części może dojść do odrzucenia skargi lub umorzenia postępowania ${ }^{90}$.

Odmienny pogląd w tej sprawie zaprezentował B. Gruszczyński. Jego zdaniem tylko w przypadku zaistnienia przesłanek odrzucenia skargi, o których mowa w art. 58 § 1 pkt 1, 4 i 5 p.p.s.a., NSA, bez względu na podstawy kasacyjne, zobowiązany jest do uchylenia zaskarżonego orzeczenia i odrzucenia skargi. Wyłącznie te przesłanki pokrywają się bowiem z podstawami nieważności postępowania (art. $183 \S 2$ pkt 1-3 p.p.s.a.), które NSA zobowiązany jest wziąć pod rozwagę. W innych przypadkach brak jest podstaw do tego, aby NSA działał z urzędu. W związku z tym zastosowanie przez ten sąd art. 189 p.p.s.a. nie tylko byłoby sprzeczne $z$ art. $183 \S 1$ p.p.s.a., ale także mogłoby naruszyć zakaz reformationis in peius ${ }^{11}$.

W uchwale składu siedmiu sędziów NSA z 8 grudnia 2009 r. (sygn. II GPS 5/09 $)^{92}$ przyjęto, że w świetle art. 183 § 1 oraz art. 134 § $2 \mathrm{w}$ zw. $z$ art. 193 p.p.s.a. jest dopuszczalne zastosowanie przez NSA z urzędu art. 189 p.p.s.a., polegające na uchyleniu orzeczenia wojewódzkiego sądu administracyjnego i odrzuceniu skargi niezależnie od zarzutów podniesionych w skardze kasacyjnej i przy braku przesłanek nieważności postępowania sądowego. Powiększony skład sądu uznał bowiem, że "niedopuszczalność skargi lub bezprzedmiotowość postępowania uniemożliwia dokonanie kontroli legalności zaskarżonego aktu, bez względu na to, czy zostało to stwierdzone na etapie rozpoznawania skargi, czy też skargi kasacyjnej, i również bez względu na to, czy następuje to z «pokrzywdzeniem» strony, czy też nie. Dlatego też nie ma tutaj zastosowania art. $134 \S 2 \mathrm{w}$ związku z art. 193 P.p.s.a.".

Już sam fakt istnienia tylu problemów interpretacyjnych powinien sugerować, że powyższy sposób rozumienia skutków odpowiedniego stosowania art. $134 \S 2$ p.p.s.a. w postępowaniu przed NSA nie jest

${ }^{90}$ Por. J.P. Tarno, Prawo..., s. 515-516.

${ }^{91}$ Zob. B. Gruszczyński, Komentarz do art. 189, w: Prawo o postępowaniu przed sądami administracyjnymi. Komentarz, pod red. B. Dautera, B. Gruszczyńskiego, A. Kabata, M. Niezgódki-Medek, Warszawa 2006, s. 447; podobnie: H. Knysiak-Molczyk, Skarga kasacyjna w postępowaniu sądowoadministracyjnym, Warszawa 2009, s. 395-397; por. też np. postanowienie NSA z 20 III 2009 r., sygn. I OZ 252/09, CBOSA.

${ }_{92}^{2}$ Uchwała składu siedmiu sędziów NSA z 8 XII 2009 r., sygn. II GPS 5/09, „ONSAiWSA" 2010, nr 3, poz. 40. 
prawidłowy. Wydaje się, że konieczne jest tu zupełnie inne podejście do rozważanej kwestii. Znamienne jest bowiem to, że do procedury sądowoadministracyjnej wprowadzono zakaz reformationis in peius, który odnosi się do postępowania przed sądem I instancji, i jednocześnie nie przewidziano analogicznej regulacji $\mathrm{w}$ przepisach dotyczących postępowania przed NSA. Jak mogłoby się wydawać, to właśnie do tego sądu, wzorem innych procedur, powinien być kierowany zakaz zmiany na gorsze, ponieważ instytucja ta w klasycznym ujęciu ograniczać ma kompetencje orzecznicze sądu II instancji. Rozwiązanie wprowadzone do Prawa o postępowaniu przed sądami administracyjnymi ma zatem niewattpliwie swoisty charakter. Analizowany tu brak w regulacji powinien być traktowany jako świadomy zabieg ustawodawcy. Należy przyjąć, że w postępowaniu sądowoadministracyjnym po prostu nie istnieje instytucja procesowa, która sprowadzałaby się do tego, że NSA nie może wydać orzeczenia na niekorzyść podmiotu wnoszącego skargę kasacyjną.

Dokonując analizy dyskusyjnej kwestii odpowiedniego stosowania art. 134 § 2 p.p.s.a. w postępowaniu przed NSA, trzeba brać pod uwagę specyfikę procedury sądowoadministracyjnej, a przede wszystkim to, czemu w istocie ona służy. Niezbędne jest także uwzględnienie kontekstu systemowego, w jakim występuje art. 134 § 2 p.p.s.a. Już samo miejsce zamieszczenia tego unormowania w ustawie wskazuje na potrzebę szczególnego sposobu interpretacji. Przepis ten - w ocenie autorki niniejszego opracowania - zawiera normę gwarancyjna, sprowadzającą się do tego, że uruchomienie sądowego postępowania kontrolnego, rozumianego jako całość tej procedury, nie spowoduje pogorszenia sytuacji prawnej skarżącego wynikającej z zakwestionowanego poprzez wniesienie skargi aktu (lub czynności). Dlatego też odpowiednie stosowanie art. $134 \S 2$ p.p.s.a. w postępowaniu przed NSA powinno polegać na tym, że również ten sąd nie może wydać orzeczenia na niekorzyść strony, która wniosła skargę, czym zapoczątkowała proces sądowej kontroli legalności aktu lub czynności organu administracji publicznej. Podkreślić zatem trzeba, że punktem odniesienia przy stosowaniu zakazu reformationis in peius przez NSA jest wciąż sytuacja prawna skarżącego wynikająca z zaskarżonego aktu lub czynności, a nie sytuacja, która została ukształtowana orzeczeniem wojewódzkiego sądu administracyjnego. Oczywiście, tu również możliwe będzie odstąpienie od powyższej zasady w sytuacji, gdy NSA dopatrzy się naruszenia 
prawa skutkującego stwierdzeniem nieważności zaskarżonego aktu lub czynności organu administracji publicznej.

W związku z powyższym NSA będzie związany tak rozumianym zakazem orzekania na niekorzyść, jeżeli skorzysta z kompetencji orzeczniczej przewidzianej $w$ art. 188 p.p.s.a. ${ }^{93}$ Przepis ten stanowi, że NSA w razie uwzględnienia skargi kasacyjnej, uchylając zaskarżone orzeczenie, rozpoznaje skargę, jeżeli uzna, że istota sprawy jest dostatecznie wyjaśniona. Orzekając na tej podstawie, NSA stosuje przepisy odnoszące się do postępowania przed wojewódzkim sądem administracyjnym (art. 145-151 p.p.s.a.) ${ }^{94}$. Aktualność zachowują tu wszystkie wcześniejsze ustalenia co do skutków obowiązywania zakazu reformationis in peius $\mathrm{w}$ postępowaniu przed sądem administracyjnym I instancji.

\section{Skuteczność instytucji zakazu reformationis in peius w postępowaniu sądowoadministracyjnym}

Niektórzy przedstawiciele doktryny wyraźnie aprobują obowiązywanie $\mathrm{w}$ postępowaniu sądowoadministracyjnym zakazu reformationis in peius ${ }^{95}$. Inni natomiast, dostrzegając zarówno zalety, jak i wady istnienia tego zakazu, traktują go jako „zło konieczne" ${ }^{\prime \prime}$. Są też jednak tacy autorzy, którzy w ogóle podważają sens istnienia tej instytucji procesowej w postępowaniu przed sądem administracyjnym. Zdaniem B. Majchrzaka, ze względu na występowanie $\mathrm{w}$ doktrynie i orzecznictwie sądowym bardzo poważnych rozbieżności interpretacyjnych w zakresie sposobu określenia konsekwencji obowiązywania zakazu reformationis in peius w postępowaniu sądowoadministracyjnym, najlepszym rozwiązaniem byłoby uchylenie art. $134 \S 2$ p.p.s.a. Autor ten uważa bowiem, że deklarowana funkcja wspomnianego zakazu w praktyce nie jest realizowana, a ponadto w żaden sposób nie da się jej wypełnić. Jednocześnie

${ }^{93}$ Podobny pogląd, sprowadzający się do tego, że NSA, orzekając na podstawie art. 188 p.p.s.a., związany jest zakazem reformationis in peius, prezentuje M. Federczyk. Autor ten nie określa jednak, jaką dokładnie treść ma tu wspomniany zakaz - zob. W. Federczyk, op. cit., s. 162; pogląd ten aprobuje też J.P. Tarno, Prawo..., s. 350.

${ }^{94}$ Por. J. Drochal, A. Wiktorowska, R. Stankiewicz, Komentarz do art. 188, w: Prawo..., pod red. R. Hausera, M. Wierzbowskiego, s. 715.

${ }^{95}$ Zob. E. Ochendowski, op. cit., s. 223; B. Adamiak, op. cit., s. 441.

${ }^{96}$ Zob. T. Woś, Komentarz do art. 134, w: Prawo..., pod red. T. Wosia, s. 796; J. Zimmermann, Zakaz..., s. 354. 
B. Majchrzak podkreśla, że ewentualne zmiany treści przedmiotowej regulacji nie przyniosłyby żadnego efektu, ponieważ obecny stan rzeczy nie wynika $z$ niewłaściwego brzmienia analizowanego przepisu, ale $z$ tego, iż w postępowaniu przed wojewódzkim sądem administracyjnym po prostu nie ma miejsca na obowiązywanie zakazu orzekania na niekorzyść skarżącego ${ }^{97}$. Z powyższym poglądem można się zgodzić jedynie w zakresie dotyczącym oceny skuteczności wspomnianego zakazu. Rzeczywiście, norma zawarta w art. $134 \S 2$ p.p.s.a. nie jest w stanie zapewnić skarżącemu efektywnej ochrony przed pogorszeniem jego sytuacji prawnej. W każdym przypadku, gdy sąd administracyjny, uwzględniając skargę, wyda wyrok kasacyjny, otwarta zostaje droga do podjęcia przez organ administracji rozstrzygnięcia mniej korzystnego niż zaskarżone. Oznacza to, że "wygrana" skarżącego w sprawie sądowoadministracyjnej nie zawsze doprowadzi do osiągnięcia oczekiwanego efektu w postaci uzyskania w sprawie administracyjnej rozstrzygnięcia korzystniejszego niż zaskarżone, ale też - co ważniejsze - może skutkować finalnym pogorszeniem sytuacji prawnej podmiotu, który zdecydował się wnieść skargę do sądu administracyjnego. Dostrzeżenie tego problemu nie powinno jednak prowadzić do uznania słuszności tezy, zgodnie z która prawidłowym rozwiązaniem byłoby usunięcie $\mathrm{z}$ porządku prawnego art. $134 \& 2$ p.p.s.a. Przepis ten zawiera bowiem normę gwarancyjną o fundamentalnym znaczeniu. Należy raczej zastanowić się, czy w jakikolwiek sposób można udoskonalić regulację prawną.

Przede wszystkim warto zwrócić uwagę, że niezwykle rzadko sąd administracyjny swoim wyrokiem bezpośrednio kształtuje sytuację prawną strony. Sąd ten zasadniczo znosi jedynie wadliwe rozstrzygnięcia organów administracji publicznej i wówczas wyłącznie pośrednio może wywierać wpływ na kształt rozstrzygnięć, które mają zapaść w przyszłości. Nigdy jednak nie ma pewności, że poprzez oceny prawne i wskazania co do dalszego postępowania sąd będzie w stanie zagwarantować stronie niepogorszenie jej sytuacji prawnej. Konieczność wydania przez organ administracji publicznej rozstrzygnięcia mniej korzystnego niż zaskarżone wynikać może przede wszystkim ze zmiany stanu prawnego lub faktycznego sprawy. Pomimo tych realiów ustawodawca nie stworzył żadnego unormowania wprowadzającego zakaz reformationis in peius $\mathrm{w}$ postępowaniu przed organem administracji publicznej toczącym się wskutek wydania przez sąd administracyjny wyroku

${ }^{97}$ Zob. B. Majchrzak, op. cit., s. 50. 
kasacyjnego ${ }^{98}$. Ochroną dla skarżącego z pewnością nie jest nawet art. 139 k.p.a. ${ }^{99}$, ponieważ w przepisie tym ustanowiono zakaz zmiany na gorsze chroniący odwołującą się stronę. Punktem odniesienia jest zatem w tym przypadku sytuacja prawna strony wynikająca z decyzji organu I instancji, a nie sytuacja prawna skarżącego ukształtowana decyzją zaskarżoną do sądu administracyjnego.

Generalnie przepis przewidujący zakaz reformationis in peius należy postrzegać przede wszystkim jako normę gwarancyjną, a nie tylko jako unormowanie dotyczące kompetencji orzeczniczych danego organu lub sądu. Dlatego też trzeba przyjąć, że w przypadku, gdy w administracyjnym postępowaniu odwoławczym dochodzi do wydania decyzji kasacyjnej na podstawie art. $138 \S 2$ k.p.a., obowiązek przestrzegania zasady zakazu reformationis in peius przeniesiony zostaje na ponownie orzekający w sprawie organ I instancji, ponieważ wyraźnie wskazuje na to wykładnia celowościowa i systemowa art. 139 k.p.a. ${ }^{100}$ Trudno jednak byłoby uznać, że z faktu, iż sąd administracyjny związany został zakazem orzekania na niekorzyść skarżącego, można wywodzić ograniczenie kompetencji orzeczniczych organu administracji publicznej. Przede wszystkim przeszkodą dla takiej interpretacji jest to, że mamy tu do czynienia z podmiotami należącymi do różnych rodzajów władzy publicznej - sądowniczej i wykonawczej. Ponadto postępowanie sądowoadministracyjne to odrębnie uregulowana procedura. Dodatkowo trzeba zaznaczyć, że sąd administracyjny, poza wyraźnie wskazanymi sytuacjami, nie jest uprawniony do władczego wyznaczenia kierunku rozstrzygnięcia organowi ponownie rozpatrującemu sprawę. Takiego działania sądu z pewnością nie można byłoby zakwalifikować jako elementu wskazań co do dalszego postępowania, o których mowa w art. $141 \S 4$ p.p.s.a. Wobec powyższego wydaje się, że bez odpowiednich działań legislacyjnych nie rozwiąże się analizowanego problemu.

Instytucja zakazu reformationis in peius, jako teoretyczna konstrukcja procesowa zakreślona w sposób ogólny, dla każdej dziedziny prawa powinna przyjmować treść, która dostosowana będzie do potrzeb

${ }^{98}$ Również K. Gruszecki fakt ten postrzega jako mankament regulacji - zob. K. Gruszecki, op. cit., s. 34 .

${ }^{99}$ Odmienne stanowisko zajmuje K. Gruszecki, którego zdaniem obowiązywanie owego przepisu skutkuje tym, że wyrok sądu administracyjnego uchylający jedynie decyzję organu II instancji nie doprowadzi do pogorszenia sytuacji strony - zob. K. Gruszecki, op. cit., s. 34 .

${ }^{100}$ Zob. szerzej: A. Ciesielska, Zakaz reformationis in peius a decyzja kasacyjna z art. 138 $\S 2$ kodeksu postępowania administracyjnego, "CASUS” 2016, nr 83 (zima), s. 30 i n. 
i specyfiki danej procedury ${ }^{101}$. W ujęciu modelowym wspomniane ograniczenie kompetencji orzeczniczych adresowane jest do organu lub sądu, który rozpoznaje środek zaskarżenia. Ten komponent analizowanej instytucji nie musi być jednak traktowany jako jej immanentny składnik. Potwierdzeniem tej tezy jest fakt obowiązywania w polskim systemie prawnym art. 443 Ustawy z dnia 6 czerwca 1997 r. - Kodeks postępowania karnego ${ }^{102}$. W ocenie autorki niniejszego tekstu w procedurze sądowoadministracyjnej powinna zostać wykorzystana właśnie taka nietypowa odmiana zakazu reformationis in peius.

Aby osiągnąć cel w postaci zapewnienia skarżącemu gwarancji, że wniesienie przez niego środka zaskarżenia nie spowoduje pogorszenia jego sytuacji prawnej, do przepisów Prawa o postępowaniu przed sądami administracyjnymi musiałoby zostać wprowadzone unormowanie ustanawiające zasadę sprowadzającą się do tego, że organ, którego działanie było przedmiotem zaskarżenia, nie może w sprawie wydać aktu lub podjąć czynności na niekorzyść skarżącego. Oczywiście, od tej zasady musiałyby istnieć wyjątki zsynchronizowane z tymi, które pozwalają na odstąpienie od zakazu reformationis in peius przez sąd administracyjny. Wydaje się jednak, że przewidziany obecnie w art. 134 $\S 2$ p.p.s.a. wyjątek w postaci okoliczności stwierdzenia przez sąd naruszenia prawa skutkującego stwierdzeniem nieważności zaskarżonego aktu lub czynności jest zbyt wąski. Dlatego też jednocześnie z wprowadzeniem nowego ograniczenia kompetencji orzeczniczych organów administracji publicznej ponownie rozpatrujących sprawę należałoby rozszerzyć zakres odstępstw od mającego występować w dwóch przepisach p.p.s.a. zakazu reformationis in peius. Zakaz ten nie powinien mieć bowiem zastosowania także w przypadkach wykrycia wad aktu dających podstawę do wznowienia postępowania administracyjnego. Już od wielu lat w doktrynie podnoszony jest postulat dotyczący konieczności wprowadzenia tego właśnie wyjątku od zakazu zmiany na gorsze wiążącego sąd administracyjny ${ }^{103}$.

${ }^{101}$ Por. A.N. Wróblewski, op. cit., s. 73.

102 Tekst jedn. Dz.U. 2016, poz. 1749 ze zm. Przepis ten stanowi: „W razie przekazania sprawy do ponownego rozpoznania wolno $\mathrm{w}$ dalszym postępowaniu wydać orzeczenie surowsze niż uchylone tylko wtedy, gdy orzeczenie to było zaskarżone na niekorzyść oskarżonego albo na korzyść oskarżonego w warunkach określonych w art. $434 \S 4$. Nie dotyczy to orzekania o środkach zabezpieczających wymienionych w art. 93a § 1 Kodeksu karnego".

${ }^{103}$ Jeszcze przed wejściem w życie ustawy o NSA Z. Janowicz podkreślał, że w przypadku takich wad decyzji zakaz reformationis in peius nie może być ograniczeniem dla 
Gdyby prawodawca zdecydował się na ustanowienie zaproponowanej wyżej zasady, poziom ochrony interesu skarżącego zwiększyłby się w sposób znaczący. Skutki obowiązywania nowej normy gwarancyjnej sprowadzałyby się do tego, że organ administracji publicznej ponownie rozpatrujący sprawę wskutek wydania przez sąd wyroku kasacyjnego na samym końcu procesu stosowania prawa musiałby porównać sytuację prawną strony wynikającą z zaskarżonego do sądu aktu z sytuacja, która byłaby konsekwencją wydania aktu zaprojektowanej treści. W przypadku ustalenia przez organ, że doszłoby do wydania orzeczenia na niekorzyść strony, wyraźna podstawa prawna obligowałaby go do podjęcia rozstrzygnięcia tożsamego z tym, które było zakwestionowane poprzez wniesienie skargi.

Rzecz jasna, ewidentną wadą takiego rozwiązania jest to, że niejednokrotnie dochodziłoby do naruszenia zasady legalizmu. Taki skutek wystąpi chociażby ze względu na zmianę stanu prawnego. Trzeba jednak zwrócić uwagę, że generalnie kwestia funkcjonowania w procedurze administracyjnej i sądowoadministracyjnej zakazu reformationis in peius wzbudza wiele wątpliwości wśród przedstawicieli doktryny. $Z$ istoty tego zakazu wynika bowiem, że w imię wartości, jaką jest ochrona interesu indywidualnego, godzimy się nawet na wydanie rozstrzygnięcia niezgodnego z obowiązującym prawem ${ }^{104}$. Wobec tego wprowadzenie zaproponowanej normy, adresowanej do organów administracji publicznej, nie byłoby czymś bardziej kontrowersyjnym niż obecne obowiązywanie analogicznych unormowań w szeroko rozumianym prawie administracyjnym. Takie uzupełnienie regulacji zapewniłoby jednak rzeczywistą gwarancję skarżącemu, że jego sytuacja prawna nie ulegnie pogorszeniu w wyniku wniesienia skargi do sądu administracyjnego.

\section{Podsumowanie}

Ze względu na szczególną funkcję postępowania sądowoadministracyjnego duże kontrowersje wywołuje już sam fakt obowiązywania w tej procedurze zakazu reformationis in peius. Wielość problemów interpretacyjnych, pojawiających się przy ustalaniu treści tego zakazu, pogłębia

sądu administracyjnego - zob. Z. Janowicz, Kodeks postępowania administracyjnego. Komentarz, Warszawa-Poznań 1995, s. 491; por. też np.: K. Gruszecki, op. cit., s. 34; T. Woś, Komentarz do art. 134, w: Prawo..., pod red. T. Wosia, s. 797.

${ }^{104}$ Por. J. Zimmermann, Zakaz..., s. 352 i n. 
wątpliwości przedstawicieli doktryny co do sensu istnienia tej instytucji procesowej. Wydaje się jednak, że niewłaściwym rozwiązaniem byłoby wyeliminowanie z procedury sądowoadministracyjnej zakazu orzekania na niekorzyść skarżącego. Zakaz ten stanowi bowiem gwarancję procesową o fundamentalnym znaczeniu dla ochrony interesu skarżącego. Dlatego też wskazane jest dążenie do zapewnienia rzeczywistej skuteczności funkcjonowania instytucji gwarancyjnej, będącej przedmiotem niniejszych rozważań, a nie jej usunięcia. Dla osiągnięcia tego celu konieczne byłoby upowszechnienie nieco odmiennego od ugruntowanego w doktrynie i orzecznictwie podejścia do mechanizmu stosowania zakazu reformationis in peius przez sądy administracyjne. Obecny kształt art. 134 \& 2 p.p.s.a. jest jednak wynikiem czerpania przez ustawodawcę z wzorców cywilistycznych i w drodze właściwej wykładni jedynie nieznacznie można poprawić skuteczność tej normy. Zasadne wydaje się zatem dostosowanie regulacji dotyczącej zakazu reformationis in peius do specyfiki postępowania sądowoadministracyjnego. Istota proponowanych zmian sprowadza się do tego, że oprócz zakazu zmiany na gorsze wiążącego sąd administracyjny powinno istnieć normatywne ograniczenie kompetencji orzeczniczych organu administracji publicznej rozpatrującego sprawę po wydaniu przez sąd wyroku kasacyjnego. Tylko dzięki takiemu niestandardowemu rozwiązaniu możliwa byłaby znacząca poprawa efektywności ochrony przed pogorszeniem sytuacji prawnej podmiotu wnoszącego skargę do sądu administracyjnego.

\section{ISSUES RELATED TO THE PROHIBITION OF REFORMATIO IN PEIUS IN ADMINISTRATIVE COURT PROCEEDINGS}

\section{Su m mary}

The principle of prohibition of reformatio in peius is established in Article $134 \S 2$ of the Law on Proceedings Before Administrative Courts. According to this provision the administrative court is not allowed to issue a decision to the detriment of the complainant. A judgment adverse to the complainant can be exceptionally issued but only if the court finds a violation of the law resulting in the annulment of the challenged act or action. This principle is a procedural institution which ensures that the complainant's situation will not deteriorate due to the decision of the administrative court.

There are many interpretative doubts concerning the prohibition of reformatio in peius in the doctrine and the jurisdiction of the administrative courts. This is 
because administrative courts very rarely issue a decision on the merits. Decisions of administrative courts are basically of cassation nature. When the administrative court allows a complaint, the contested act is generally eliminated from the system of law and the case is returned for re-examination by the public administrative authority. It is therefore very difficult to determine the content of the prohibition of reformatio in peius in administrative court proceedings and in practice the prohibition of a change for the worse is not a real guarantee of the protection of the interests of the complainant.

In the author's opinion, the way of approaching the mechanism of application of the prohibition of reformatio in peius by the administrative courts needs to be changed. And yet, a significant improvement in the effectiveness of the protection against the worsening of the complainant's legal situation will only be possible through the introduction of a new legal regulation restricting the jurisdiction of public administrative authority, which will reconsider the case after the cassation judgment issued by the administrative court.

Keywords: administrative court proceedings - prohibition of reformatio in peius complaint to the administrative court - judgment to the detriment of the complainant 